\begin{tabular}{|l|l|l|l|l|l|}
\hline MUNIBE Antropologia-Arkeologia & $n^{\circ} 68$ & $179-195$ & DONOSTIA & 2017 & ISSN $1132-2217 \cdot$ elSSN $2172-4555$ \\
\hline
\end{tabular}

\title{
Pottery and regional mobility in southern Sardinia (Italy) during the Early Copper Age: A petrological approach
}

\author{
Cerámica y movilidad regional en el sur de Cerdeña (Italia) \\ durante la Primera Edad del Cobre: Una aproximación petrológica
}

PALABRAS CLAVES: Petrología, Procedencia de materias primas, Movilidad, Cerámica, Calcolítico. GAKO-HITZAK: petrologia, lehengaien jatorria, mugigarritasuna, zeramika, kalkolitikoa. KEY WORDS: Petrology, Raw materials origin, Mobility, Ceramics, Chalcolithic.

Daniel ALBERO SANTACREU(1) and Maria GRAZIA MELIS(2)

\section{RESUMEN}

Se ha realizado el análisis petrológico de cerámicas del yacimiento calcolítico de Su Coddu/Canelles (Cerdeña) con el objetivo de identificar las materias primas utilizadas en la producción de cerámica y aproximarnos al origen de las vasijas. El estudio petrológico confirma la existencia de cerámicas relacionadas con una amplia diversidad de procedencias. Por un lado, se constatan una serie de fábricas que son compatibles con los depósitos arcillosos que se encuentran en el entorno del yacimiento. Por otro lado, se han identificado una serie de fábricas que deben asociarse con arcillas o vasijas con un origen regional o incluso supra-regional. La existencia de estas fábricas en el yacimiento evidencia que las comunidades calcolíticas del sur de Cerdeña desarrollaron una amplia movilidad en el territorio isleño, tanto a nivel local como regional. Esta amplia movilidad es indicativa de las interacciones y vínculos que establecieron las diversas comunidades que habitaban la región. En última instancia, la investigación realizada ha permitido aportar luz sobre el tipo de movilidad que desarrollaron las comunidades de la Edad del Cobre de las grandes islas del Mediterráneo y sobre cómo éstas llevaron a cabo la explotación de una amplia variedad de tipos de depósitos arcillosos.

\section{LABURPENA}

Su Coddu/Canelles-eko (Sardinia) aztarnategi kalkolitikoko zeramiken azterketa petrologikoa egin da zeramika produzitzeko erabilitako lehengaiak identifikatu eta ontzien jatorrira gerturatzeko asmoz. Azterketa petrologikoak jatorri ugarirekin lotutako zeramikak daudela baieztatu du. Alde batetik, aztarnategiaren inguruan dauden buztin-metakinekin bateragarriak diren lan batzuk ikusi dira. Bestalde, eskualdeko jatorria edo eskualdez gaindikoa izan daitekeen jatorria duten buztinekin edo ontziekin lot ditzakegun lan batzuk identifikatu dira. Aztarnategian lan horiek topatu izanak agerian utzi du Sardiniako hegoaldeko komunitate kalkolitikoek uhartean mugigarritasun handia izan zutela toki zein eskualde mailan. Mugikortasun handi horrek agerian uzten du eskualdean bizi ziren komunitate ugarien artean loturak eta elkarrekintzak egon zirela. Azken batean, egindako ikerketak Mediterraneoko uharte handietako komunitateek Kobre Aroan zer mugigarritasun mota izan zuten eta buztin-metakin mota ugari nola ustiatu zuten erakutsi ahal izan du.

\section{ABSTRACT}

The petrological analysis of ceramics from the Early Chalcolithic site of Su Coddu/Canelles (Sardinia) was conducted with the aim of identifying the raw materials used in the pottery production and assessing their origin. The petrological analysis confirms the existence of vessels related to a wide diversity of sources at the site. On the one hand, there are a number of fabrics associated with the use of marly clays that well resemble the clay deposits found in the area surrounding the site. On the other hand, there are some fabrics that must be associated with clays or vessels with a regional or even a supra-regional origin. The existence of several fabrics with diverse origins indicates that Early Copper Age communities of southern Sardinia exhibited a wide mobility in the territory, both at the local and regional level. This broad mobility is indicative of interactions and bonds between the inhabitants of diverse communities in the region. Thus, this research sheds light on the way Chalcolithic communities inhabiting one of the biggest islands of the Mediterranean developed a significant mobility pattern and carried out the exploitation of a wide range of local clayey raw materials.

\section{1.- INTRODUCTION}

Mobility is a key aspect in the adaptation of human groups to the physical and social environment. Individuals' mobility is closely connected with the particular concept of space and time that develops in each society (Sheller \& Urry, 2006). Consequently, space and time are contingent categories that can change significantly from one society to another (Skeggs, 2004). Thus, mobility becomes a dynamic and cultural component that

\footnotetext{
(1) Department of Historical Sciences and Arts Theory, University of the Balearic Islands (Spain). Ramon Llull, Campus UIB, Ctra. Valldemossa km 7.5 s/n 07122 Palma, Spain. Corresponding author: d.albero@uib.es.

(2) Department of History, Human Sciences and Education, University of Sassari (Italy).
} 
influences the way the natural and social environment is conceived, perceived and known. Moreover, it is an active element that articulates the territory and promotes the creation of specific humanized spaces and identities among the communities. In short, mobility is a mechanism that allows the existence of spaces for dialogue and social interaction (Broodbank, 1993).

Local, regional and trans-regional connections enable the exchange of certain ideas and a specific material culture. This exchange and interaction not only favors the creation of networks of contacts but also their maintenance in a back and forth process. Therefore, the dynamics of movement are fully involved in the formation of particular social structures. They are structural phenomena of the societies that are at the same time structured by people through meaning, identity and practice (Cresswell, 2010). The relationships and connections established between different communities in a specific area of action are, then, one of the basic principles governing social life, and these relationships are materialized in a particular material culture and its distribution through the territory. The study of mobility is, therefore, crucial to assessing the existence of such connections and identifying the role played by material culture in the socio-cultural interaction that takes place between human communities, at both the internal and external levels.

Having these theoretical viewpoints in mind and the need to identify individuals' mobility in the past, we have conducted a petrological analysis of a ceramic assemblage unearthed at the archaeological site of Su Coddu/ Canelles (Selargius, Cagliari). The main objective of this analysis is to identify the local or regional sources of origin of the vessels with the aim to address the mobility of the communities of southern Sardinia during the Early Chalcolithic (second half of the IV millennium BC). Sardinia with $24.100 \mathrm{~km}^{2}$ is the second largest island in the Mediterranean Sea, implying a huge territory. Thus, our research strategy and case study will allow us to approach the way mobility took place in one of the biggest islands of the Mediterranean during the Copper Age through the analysis of the pottery produced and exchanged by the local communities.

Prehistoric hand-made pottery is usually thought to have been produced in domestic contexts and had a limited mobility in a given territory. However, it is clear from ethnographic cases (e.g. Arnold, 1985; Calvo et al., 2013) and archaeological evidence (e.g. Neff, 2014; Quinn et al., 2010; Hommel et al., 2016; Jordan et al., 2016) that hand-made pottery is often involved in regional networks that may include tens of kilometres or even more distant contacts. In this sense, the morphological, decorative and typological homogeneity observed in Chalcolitic pottery from Sardinia (Melis, 2000, table 102) already points to a significant social interaction and exchange of ideas at both medium and long-distance scales among the diverse sites on the island. For instance, the typological and decorative features of the pottery recorded at the archaeological site of Su Coddu/Canelles (Southern Sardinia) are also observed at other sites in Central Sardinia (e.g. Fenosu, Cuccuru s'Arriu, S. Giovanni Battista, Iloi, Motorra) as well as in Northwest Sardinia (e.g. Sa Ucca de su Tintirriolu, Monte d'Accoddi, Anghelu Ruju, Mesu 'e Montes), among many other places (Fig. 1).

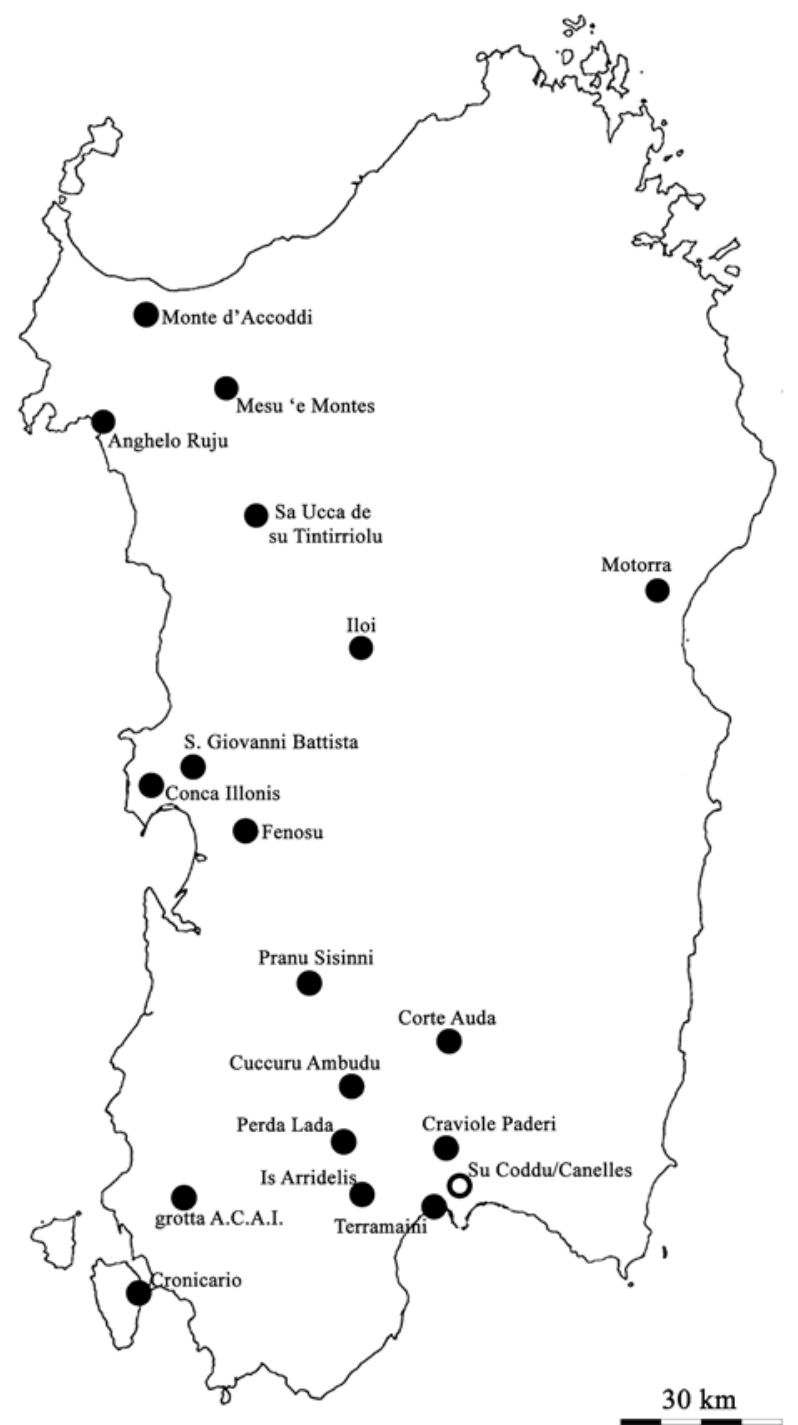

Fig. 1. Map of Sardinia showing the location of Su Coddu/Canelles and other archaeological sites with ceramic assemblages of similar typological and decorative features (adapted from MELIS, 2000)./ Mapa de Cerdeña mostrando la localización de Su Coddu/Cannelles y otros yacimientos arqueológicos con restos cerámicos de similar tipologia y motivos decorativos (adaptado de MELIS, 2000).

Even though these data justify certain exchange of ideas and knowledge regarding pottery production among the Chalcolithic communities in Sardinia, evidence about the actual mobility of ceramics and individuals is rather limited. In this sense, our goal is to address the mobility of individuals and vessels by means of the petrological analysis of the pottery recovered at Su Coddu/Canelles and its possible relationship with the diffe- 
rent local and regional clay deposits that are present in the area. In addition, we will relate the petrological data to the spatial distribution of Chalcolithic sites identified in the region. This strategy of analysis will allow us to determine the possible sources of origin of the raw materials used in the manufacture of ceramics and to relate this information to the mobility of the human groups, either through the procurement of the clays used to produce the vessels or the distribution of already manufactured pottery. Summing up, the objectives of this study are first, to characterize the petrological composition of the pottery; second, to identify the clay sources exploited and establish their local or regional origin; and third, to make assumptions about the archaeological sites potentially involved in the production and distribution of the vessels deposited in Su Coddu/Canelles.

\section{ARCHAEOLOGICAL CONTEXT}

The emergence and widespread of the Ozieri culture is recorded throughout the island of Sardinia for the 4th millenium cal. BC, together with a significant population growth in this territory. This culture coincides with the Late Neolithic (Ozieri I, c. 4000-3500 BC) and Early Eneolithic/Chalcolithic (Ozieri II, c. 3500-3000 $\mathrm{BC})$ transition. As aforementioned, the cultural homogeneity observed throughout the island is reflected on certain pottery shapes and decorative techniques from distant archaeological sites at this period. In addition, the existence of regional mobility networks is also attested by the widespread use of the so-called domus de janas (i.e. hypogeum structures related to collective funerary practices), which are distributed throughout Sardinia. Similarly, the movement of certain raw materials has also been demonstrated, such as the obsidian extracted from Monte Arci (in western-central Sardinia), distributed along the island, or the flint from Perfugas (Northern Sardinia), which reached the territories to the south (Melis, 2000, in press).

The gradual transition between the Late Neolithic and the Early Chalcolithic along the 4th millennium cal. $\mathrm{BC}$ was characterized by the persistence of many features from the Neolithic tradition, but also by the progressive introduction of innovations and changes. Such transformations triggered significant modifications in the 4th millennium BC pottery assemblages. Materials from the Ozieri I phase are defined by the wide repertoire of vessels besides their rich decorations. Decorative motifs were often uniformly arranged covering the complete external surface (and part of the internal side) of the vessels and resorted to a broad diversity of techniques (e.g. engraving, impressing, excision, painting or plastic decorations), thus creating a complex ornamental syntax. Most of the ceramic repertoire observed in the previous phase continued in Ozieri II times; however, the vessels were now only sporadically decorated and the motifs were restricted to certain areas of the external surface of the vessels. This lack of interest in ornamental aspects coincided with the introduction of new surface treatments containing ochre, thus suggesting some kind of reorganization of the production process and the reduction of the time spent in decorating the vessels (Melis \& Piras, 2012).

According to radiocarbon dates, the archaeological site of Su Coddu/Canelles represents a good example of this gradual transition (Melis, 2013). This archaeological site -together with San Benedetto (the only closed archaeological context related to the Ozieri I culture excavated so far)- has provided the most important series of radiocarbon datings for the period (Table 1). The

\begin{tabular}{|c|c|c|c|c|c|}
\hline Archaeological site/context & Lab. number & BP & Cal BC & Prob. & Phase \\
\hline San Benedetto & AA78328 & $5044 \pm 58$ & $3960-3709$ & $95.4 \%$ & \multirow{6}{*}{ Ozieri I } \\
\hline San Benedetto & AA78330 & $4984 \pm 52$ & $3942-3655$ & $95.4 \%$ & \\
\hline San Benedetto & AA78329 & $4969 \pm 52$ & $3940-3648$ & $95.4 \%$ & \\
\hline \multirow{3}{*}{ San Benedetto } & \multirow{3}{*}{ Beta-72233 } & \multirow{3}{*}{$4920 \pm 70$} & $3920-3880$ & \multirow{3}{*}{$95.4 \%$} & \\
\hline & & & $3810-3630$ & & \\
\hline & & & $3570-3540$ & & \\
\hline \multirow{2}{*}{ Canelles, str. 134, US 1206} & \multirow{2}{*}{ LTL2930A } & \multirow{2}{*}{$4708 \pm 45$} & $3640-3550$ & $27.5 \%$ & \multirow{2}{*}{ Ozieri I-II } \\
\hline & & & $3540-3370$ & $67.9 \%$ & \\
\hline \multirow{2}{*}{ Canelles, str. 39, US 1038} & \multirow{2}{*}{ LTL295A } & \multirow{2}{*}{$4554 \pm 45$} & $3380-3090$ & $54.6 \%$ & \multirow{7}{*}{ Ozieri II } \\
\hline & & & 3375 - 3262 & $37 \%$ & \\
\hline Canelles, str. 39, US 1085 & LTL1104A & $4512 \pm 50$ & $3365-3051$ & $91.6 \%$ & \\
\hline Canelles, str. 46b, US 1202 & LTL2931A & $4481 \pm 50$ & $3360-3010$ & $95.4 \%$ & \\
\hline Canelles, str. 46b, US 1186 & LTL2932A & $4350 \pm 50$ & $3100-2880$ & $95.4 \%$ & \\
\hline \multirow{2}{*}{ Canelles, str. 47, US 1081} & \multirow{2}{*}{ LTL1105A } & \multirow{2}{*}{$4345 \pm 40$} & $3090-3051$ & $7.8 \%$ & \\
\hline & & & $3031-2890$ & $87.6 \%$ & \\
\hline
\end{tabular}

Table 1: Radiocarbon datings from the archaeological sites of San Benedetto and Su Coddu/Canelles. / Dataciones de radiocarbono de los yacimientos de San Benedetto y Su Coddu/Cannelles. 
settlement of Su Coddu/Canelles is located in southern Sardinia, close to a large number of marine and inland water bodies. Radiocarbon dating of bone fragments recovered from diverse buildings in the village indicates that the village was occupied over a long period (Table 1). The oldest part of the settlement (Su Coddu) was founded during the first half of the 4th millennium cal. BC (Ozieri I phase). The settlement gradually extended to the south during the course of the Early Copper Age (Ozieri II phase) and occupied a new large area (Canelles), which was still inhabited during the first centuries of the 3rd millennium cal. BC (Melis, 2013). The southern area, Canelles (the source of the samples analysed in this article), occupies approximately 1.5 hectares and includes up to 12 structures (Melis, 2005). These structures are partially dug in the ground and not arranged according to topographic criteria. Moreover, they have diverse shape (e.g. circular, elliptical, irregular), size and function (e.g. dwellings, combustion structures, silos, waste deposits, pole holes). They have been mainly interpreted as wells and cylindrical silos (structures 39, 43, 47 and 48). However, there is another building associated with a more complex structure (structure 46) that has a circular main room with other structures related to diverse functions, silos and ovens, attached. Organic matter imprints can be observed in many mud fragments, adobe bricks and coatings related to these structures, thus evidencing the use of both, mud and plants to construct the walls.

The extensive excavation carried out and the subsequent interdisciplinary research coordinated by Maria Grazia Melis in Su Coddu/Canelles have made it possible to reconstruct the subsistence methods, in which agriculture played a more significant role than livestock. The abundant malacofauna unearthed at the site also confirms a strong interaction between the inhabitants of the site and the surrounding wetland resources. Craft production related to the transformation of clay, stone and hard animal materials (e.g. bone) is also well identified in the site. Simultaneously, the use of metal increases, and its transformation in situ has been confirmed by the discovery of a crucible. This increasing use of metal was accompanied by developments in spinning, weaving and basketry, as evidenced by the presence of spindle whorls, loom weights and imprints of wicker on the bases of a number of pottery artefacts, respectively.

Nearly 40 archaeological sites have been identified within $15 \mathrm{~km}$ of Su Coddu/Canelles. Of these, $42 \%$ were occupied only during the Ozieri I phase, and $29 \%$ were used exclusively during the Ozieri II phase. The remaining $29 \%$ of them were occupied in both phases. In most cases, the available data come from surface prospecting or emergency excavations carried out in urban areas. Indeed, Su Coddu/Canelles has been the only site in the area at which an extensive archaeological excavation has been undertaken. Despite the lack of accurate data regarding the area of each site, it has been possible to distinguish between smaller archaeological sites occupied only during one phase and larger long-term-use sites. Su Coddu/Canelles is classified within this latter group, since it covers an area of over 5 hectares and was occupied during Ozieri I and II phases. The archaeological sites of both phases are mainly located in farmlands, on flat or low-relief areas close to watercourses or wetlands. Archaeobotanical data indicate a landscape with diversified resources, suitable for agriculture and livestock (Melis et al., in press).

\section{GEOLOGICAL BACKGROUND}

The geology and lithology of the area surrounding Su Coddu/Canelles is quite complex (Fig. 2) and involves a wide variety of geological deposits that formed at different times (Carmignani et al., 1996; Barca et al., 2005). The archaeological site is located in Quaternary alluvial terraced deposits with abundant microfossils and granulometric heterogeneity. These deposits consist of coarse gravel, sand, aeolian sandstones, conglomerates, biocalcarenites and muds. The detrital materials originate in the granitic and metamorphic formation of the Sarrabus. Alluvial and colluvial deposits with coastal gravel, sand, silt, sandy and silty dark clays and mud rich in organic matter with fragments of marine and lagoon shells have been documented in the south of Selargius.

Substantial Lower and Middle Miocene deposits of marine origin with a contribution of continental materials were observed approximately $2.5 \mathrm{~km}$ to the east, north and west of the archaeological site. However, these grey marly clays with sand, the Argille di Fangario formation, are also found beneath the Quaternary alluvial sediments noted above. A deposit (i.e., the Marne di Gesturi formation) composed of yellow marls with sand and silt, sandstones, conglomerates, limestone and calcarenites is also observed in this area. Both clay deposits have abundant planktonic foraminifera, pelagic fauna, molluscs, echinoids, benthonic fauna and corals. Additionally, they possess pyroclastic and epiclastic facies. Additional Tertiary deposits (Middle Eocene to Early Miocene) are documented $10 \mathrm{~km}$ to the north of the site, near the village of Dolianova. These deposits are composed of sand and silt, sandstones, conglomerates, tuffites, rhyolitic tuffs, limestones with planktonic foraminifera, pelagic fauna, benthic molluscs, corals and echinoids. In addition, the Ussana formation, which is also dated to the Oligocene and Miocene, must be highlighted. This formation is located to the north of the village of Sinnai (6.5 km from Selargius) and is related to an ancient coastline with abundant conglomerates and sandstones.

Different types of non-calcareous deposits have been documented in the study area. On one hand, there are Palaeozoic metamorphic deposits approximately $7 \mathrm{~km}$ to the northwest of the site. The Upper Ordovician - Lower Carboniferous formation of Pala Manna, which 


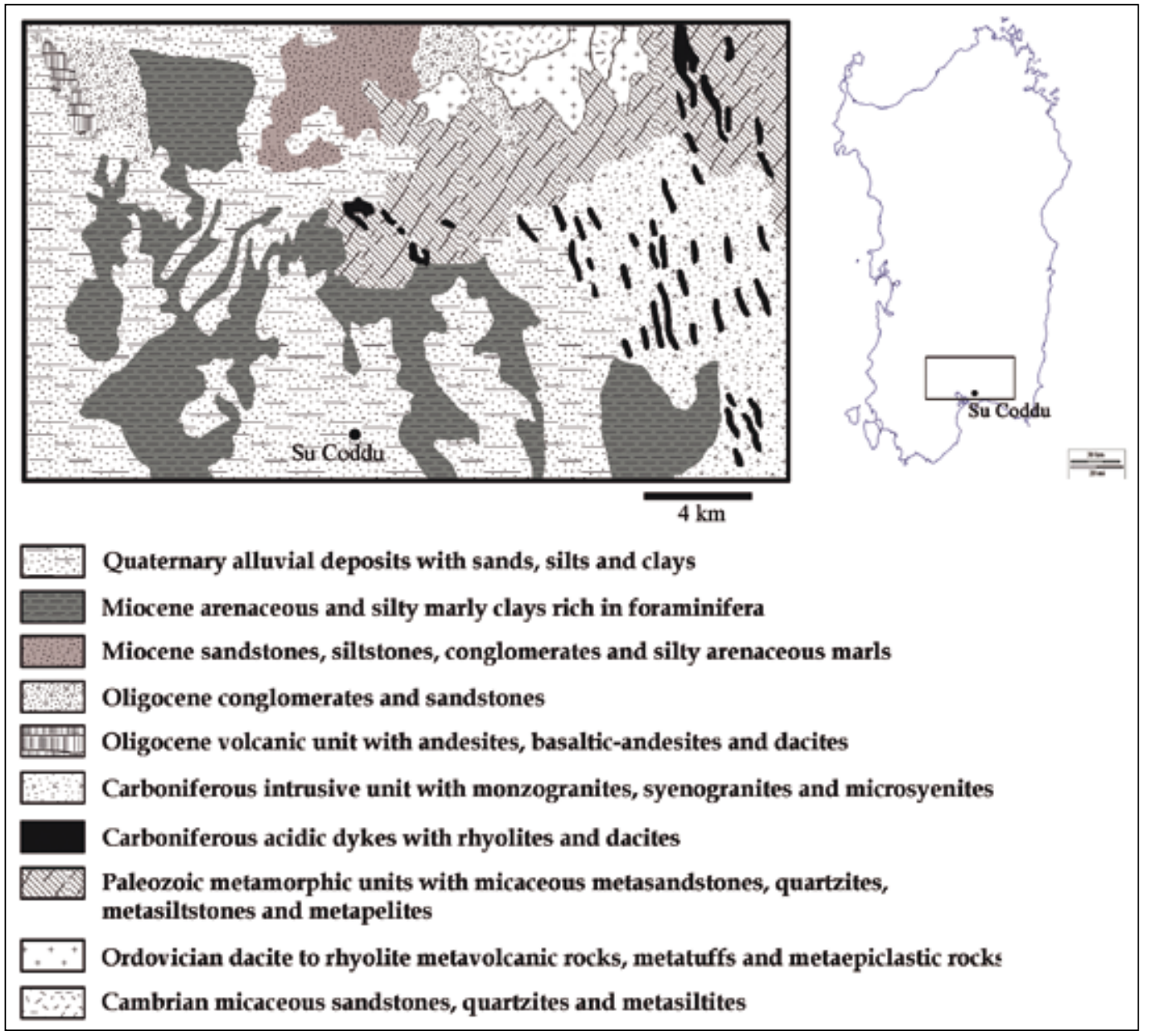

Fig. 2. Simplified geological map of the study area (Source: CARMIGNANI et al., 1996) the location of the archaeological site studied is also labeled./ Mapa geológico simplificado del área de estudio (Fuente: CARMIGNANI et al., 1996), a localización de los yacimientos arqueológicos estudiados está también indicada. is composed of meta-sandstones, meta-siltites, quartzite, phyllite, meta-conglomerates, meta-volcanic rocks, metapelites and clays, should also be noted. Further to the north, the Punta Serpeddi and the Tuviois formations also possess fine-grained meta-sandstones, micaceous meta-sandstones, meta-arkoses, micaceous quartz, meta-siltstones and quartzites interbedded with phyllites. Metapelites, conglomerates rich in quartz and meta-greywackes with bryozoans, brachiopods, trilobites and gastropods are also documented. Within the Pala Manna formation (as well as between the Pala Manna and the Ussana formations), Carboniferous-Permian materials with acidic rhyolites and to a lesser extent dacites also appear. These outcrops are larger in the area located between Sinnai and Soleminis, approximately 8 $\mathrm{km}$ from Selargius. Further north, on the southeast side of Dolianova (13 km from Selargius), several outcrops associated with the PorfidiGrigi of Sarrabus are documented. This is an Ordovician magmatic and volcano-sedimentary formation related to metavolcanic rocks (dacites and rhyolites) and meta-tuffs.

The mountain formations are located on the western side of the study area. These are Hercynian plutonic intrusive rocks associated with the San Gregorio unit located approximately $15 \mathrm{~km}$ to the west. Several porphyritic microgranite, primarily biotitic leucogranite and granodiorite outcrops form this geological unit. In addition, the previously noted Carboniferous-Permian acidic rhyolites and dacites also occasionally appear in this formation.

Finally, the presence of the Monte Zara and Monte Oladri formations in the village of Monastir (at $13 \mathrm{~km}$ northeast) must be highlighted. These rocks are related to the volcanic cycles that took place during the Oligocene and comprise basaltic andesites, andesites, basalts, lava flows, volcanic breccias and dacites.

\section{SAMPLING AND METHODS}

The ceramic assemblage studied in this paper was recovered from six structures located in a sector of the southern area of Su Coddu/Canelles: structures 39, 43, 45, 46, 47 and 48 (Table 2). The sampling strategy consisted of an exhaustive examination of the entire ceramic assemblage recovered from these structures to obtain a set of samples representative of the diversity of fabrics present in the archaeological site. A total of 41 pottery samples were selected from different stratigraphic la- 


\begin{tabular}{|c|c|c|c|c|}
\hline Sample & $\begin{array}{c}\text { Inventory } \\
\text { number }\end{array}$ & $\begin{array}{l}\text { Architectural } \\
\text { structure }\end{array}$ & $\begin{array}{l}\text { Stratigraphic } \\
\text { layer }\end{array}$ & $\begin{array}{l}\text { Petrological } \\
\text { Fabric }\end{array}$ \\
\hline C-8 & 11896 & 39 & 1067 & Fabric 3 \\
\hline C-9 & 23208 & 39 & 1067 & Fabric 8 \\
\hline C-10 & 12133 & 39 & 1067 & Subfabric 1.1 \\
\hline C-11 & 25001 & 42 & 1101 & Fabric 2 \\
\hline C-12 & 12874 & 45 & 1095 & Subfabric 1.2 \\
\hline C-13 & 954 & 43 & 1023 & Fabric 3 \\
\hline C-14 & 22441 & 43 & 1050 & Fabric 2 \\
\hline C-15 & 23209 & 39 & 1067 & Fabric 3 \\
\hline C-16 & 12252 & 45 & 1163 & Fabric 2 \\
\hline C-17 & 12303 & 45 & 1176 & Fabric 6 \\
\hline C-18 & 22411 & 43 & 1049 & Fabric 8 \\
\hline C-19 & 2766 & 43 & 1023 & Subfabric 5.2 \\
\hline C-20 & 23967 & 45 & 1179 & Subfabric 1.2 \\
\hline$C-21$ & 21218 & 43 & 1050 & Fabric 3 \\
\hline C-22 & 13084 & 45 & 1033 & Subfabric 1.4 \\
\hline C-23 & 15684 & 46 & 1166 & Fabric 2 \\
\hline C-24 & 15614 & 46 & 1154 & Fabric 2 \\
\hline C-25 & 843 & 43 & 1023 & Subfabric 5.2 \\
\hline C-26 & 2566 & 48 & 1030 & Fabric 2 \\
\hline C-27 & 24583 & 46 & 1117 & Fabric 3 \\
\hline C-28 & 8361 & 48 & 1057 & Fabric 4 \\
\hline C-29 & 7664 & 48 & 1043 & Subfabric 5.2 \\
\hline C-30 & 7670 & 48 & 1051 & Subfabric 5.1 \\
\hline C-31 & 7671 & 48 & 1051 & Subfabric 5.2 \\
\hline C-32 & 8020 & 48 & 1051 & Subfabric 5.1 \\
\hline C-33 & 3729 & 43 & 1023 & Fabric 7 \\
\hline C-34 & 6041 & 43 & 1023 & Fabric 7 \\
\hline C-35 & 25335 & 47 & 1063 & Fabric 7 \\
\hline C-36 & 7735 & 48 & 1043 & Fabric 2 \\
\hline C-37 & 25889 & 47 & 1075 & Subfabric 5.1 \\
\hline C-38 & 21945 & 43 & 1050 & Fabric 2 \\
\hline C-39 & 21240 & 43 & 1050 & Subfabric 5.2 \\
\hline C- -40 & 1639 & 43 & 1023 & Subfabric 5.2 \\
\hline C-41 & 8771 & 47 & 1063 & Subfabric 1.1 \\
\hline C-42 & 25415 & 47 & 1063 & Subfabric 1.1 \\
\hline C- 43 & 25583 & 47 & 1063 & Subfabric 1.3 \\
\hline C-44 & 8860 & 47 & 1079 & Fabric 2 \\
\hline C-45 & 25411 & 47 & 1063 & Fabric 7 \\
\hline C-46 & 24363 & 47 & 1042 & Fabric 7 \\
\hline C- 47 & 24284 & 47 & 1042 & Fabric 4 \\
\hline C-48 & 23601 & 47 & 1057 & Subfabric 5.1 \\
\hline
\end{tabular}

Table 2: Archaeological information of the samples analysed. The petrological fabric related to each sample is also included. / Información arqueológica de las muestras analizadas. También está incluido el patrón petrológico de cada muestra. yers dated in the Ozieri II phase. Therefore, the petrological analysis proposed here may provide evidence for human mobility in Sardinia during the Early Chalcolithic period. These vessels represent the diverse shapes and types present in the archaeological site (MELIS \& PIRAS, 2010): pans (C-9, C-18, C-19, C-21), vases (C-48), big vases (C-24, C-37), bowls (C-13, C-15, C-28), tripods (C-14), storage pots or dolios (C-22, C-26, C-38), carinated bowls/dishes (C-36), figuline (C-17, C-45), cooking pots (C-46) (Fig. 3).

Subsequently, we characterized the petrological composition of 41 samples using optical microscopy and thin-section analysis. The 41 selected samples were sectioned and polished for petrographic characterization by optical microscopy. The optical examination of thin sections was performed using a petrographic microscope Leica DM2500P, which incorporates a micrometre. The lenses ranged from $\times 16$ to $\times 400$ magnifications. The observation of the groundmass was systematically carried out at x400 magnifications. Photomicrographs of the samples were taken with a Leica DFC295 digital camera. The quantity of each compound was established using comparative charts (MATTHEW et al., 1991). Descriptions of the thin sections were made following the procedure developed and detailed by I. Whitbread (1995). In addition, textural concentration features (tcf) were characterized considering the observations made by I. Whitbread (1986) and N. Cuomo Di Caprio and S. Vaughan (1993).

\section{RESULTS}

Four main groups (i.e. basic igneous fabric, felsic igneous fabric, metamorphic fabric and sedimentary fabric) have been established depending on the characteristics of the matrix and the minerals and rock fragments identified in the thin sections. These groups relate to the nature of the clay deposits used in the manufacture of the vessels, and most of them include several subfabrics (Table 2).

\section{Fabric 1: Basic/intermediate Igneous Fabric ( $\mathrm{n}=7 ; 17 \%)$}

This fabric has few to very few open to double-spaced voids (2-10\%). The non-plastic inclusions are single to double-spaced and poorly oriented. The groundmass is dominant and relatively homogeneous throughout the sections. The colour is usually brown or yellowish-brown (PPL) to brown-orange (XPL). This is a stipple-speckled b-fabric with an optically active to moderately active micromass. The non-plastic inclusions range from 15 to $20 \%$ and have a bimodal grain size distribution with poorly sorted subangular to rounded rock fragments and coarse inclusions (granules to fine sand) set in a fine-grained groundmass with subrounded to rounded inclusions. The fine fraction is usually dominant, with a modal grain size of $0.12 \mathrm{~mm}$ in the long dimension (c:$f_{10 \mu}: V=24: 50: 25$ to $\left.16: 76: 8\right)$. The samples included in 

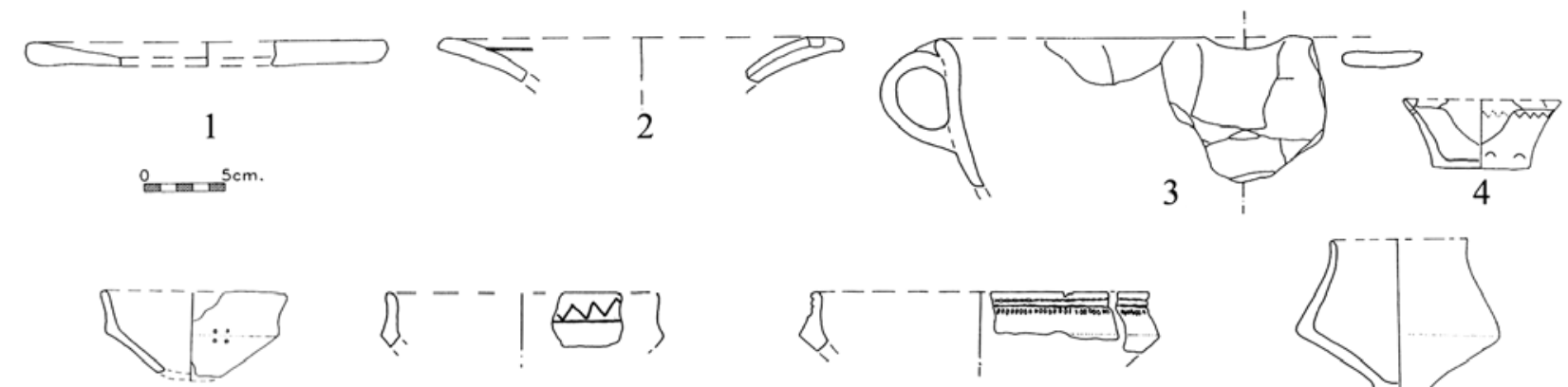

5

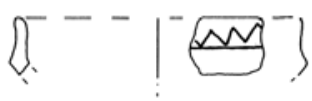

6
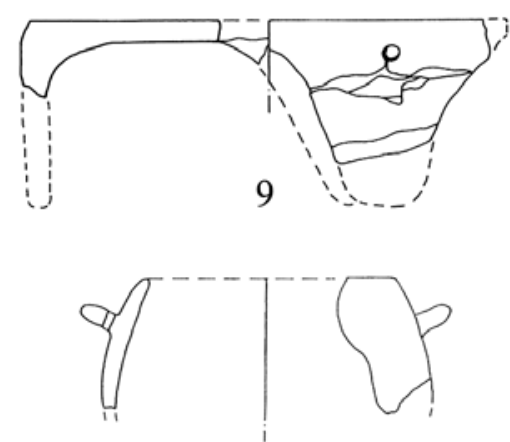

12

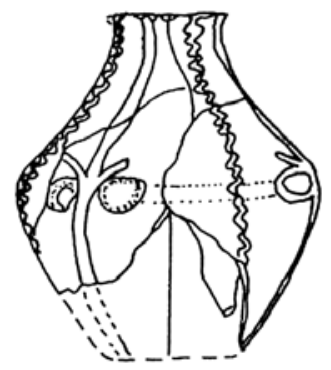

13

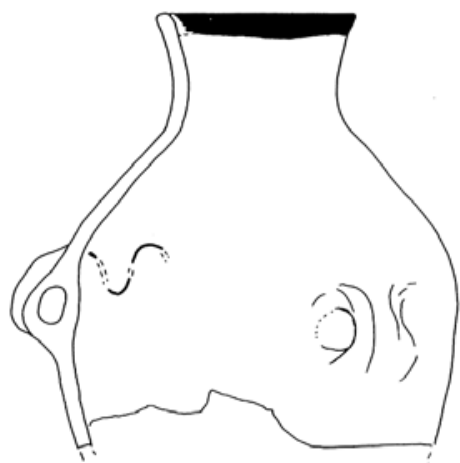

14

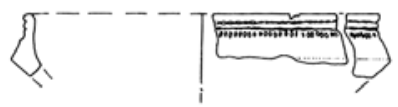

7

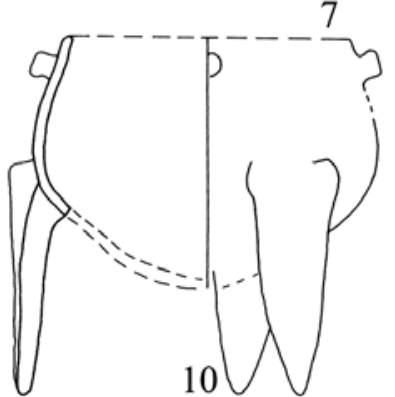

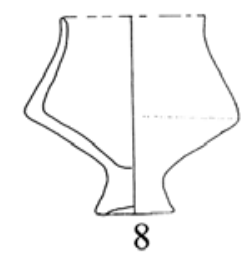

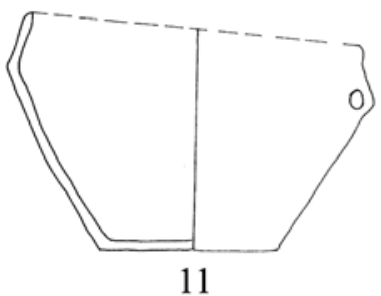

11

Fig. 3. Ozieri II phase typical pottery types: 1) flat plate; 2) plate; 3) pan; 4) tronco-conical dish; 5, 6 and 7) carenated bowls; 8) carenated cup; 9 and 10) tripods; 11) carenated vase; 12) cooking pot; 13) biconical vase, 14) long neck vase, 15) storage pot./ Típicos tipos de cerámica la fase Ozieri II: 1) plato llano; 2) plato; 3) cazuela; 4) cuenco tronco-cónico; 5,6 y 7) cuencos carenados; 8) copa carenada; 9 y 10) trípodes; 11) vaso carenado; 12) olla; 13) vaso bicónico; 14) vaso de cuello largo; 15) olla de almacenamiento.

this fabric can be attributed to a similar source of origin. However, they were classified into four subfabrics according to variations observed in their texture, the amount of basic or intermediate igneous rock fragments and the quantity of olivine, pyroxene and hornblende.

Subfabric 1.1: Fine-grained Basic Igneous Subfabric (basalt/andesite) (Figs. 4a \& 4b). Igneous basic-intermediate rock fragments (tholeiitic and plagioclasic basalts to andesite) and plagioclase are frequent in the coarse fraction of this subfabric. These rocks have a holocrystalline, microgranular or intergranular structure, virtually aphyric (fine to medium-fine grained) to moderately porphyritic with scarce euhedral plagioclase phenocrysts that are often zoned. In some cases, the matrix has been altered and shows an intergranular-subophitic texture. Common monocrystalline quartz, few clinopyroxene and few to very few olivine, orthopyroxene and biotite laths are also present in the sections. Few to absent calcimudstones, pure amorphous nodules, dolerite rock fragments and metasandstones were identified in some samples. Some textural concentration features (tcf) related to clay pellets were observed in one section.

Subfabric 1.2: Fine-grained Intermediate Igneous Subfabric (hornblende andesite) (Figs. 4c \& 4d). This subfabric is very similar to the previous fabric but differs in the presence of frequent rounded to subrounded igneous rock fragments (hornblende andesite to dacite) 
A

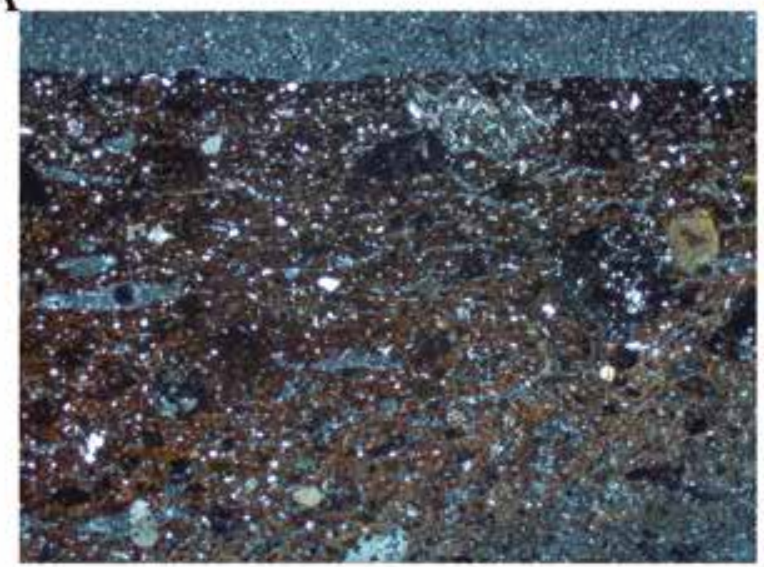

C

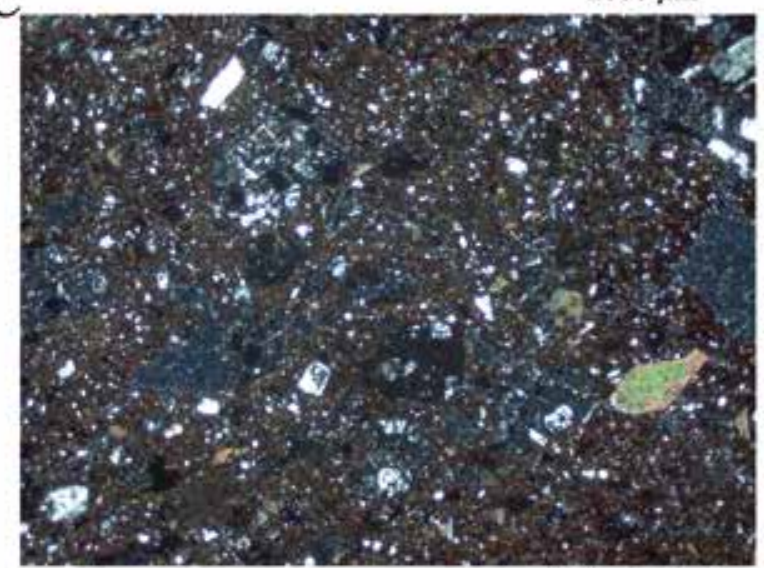

$\mathrm{E}$

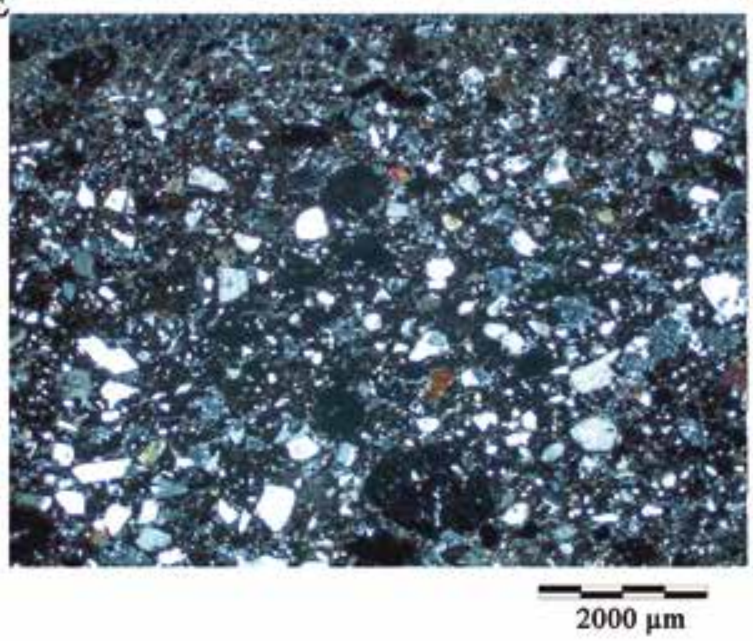

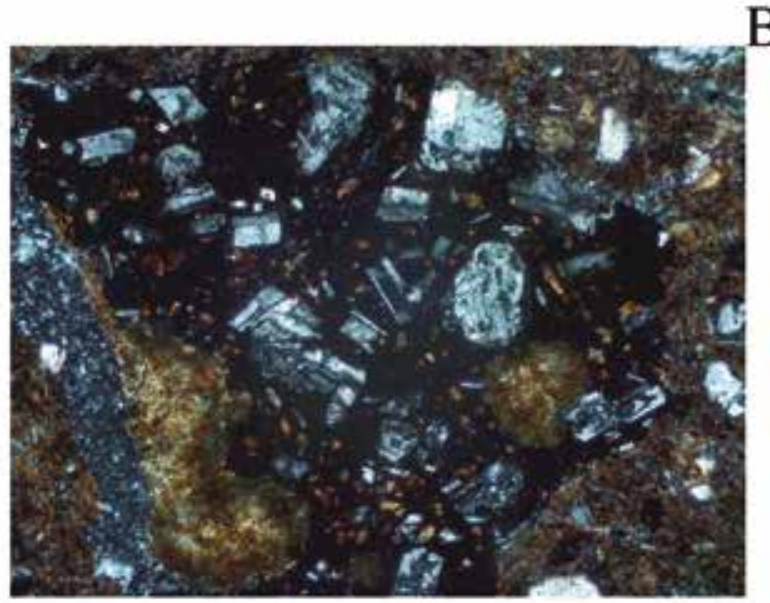

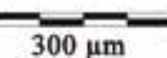

D

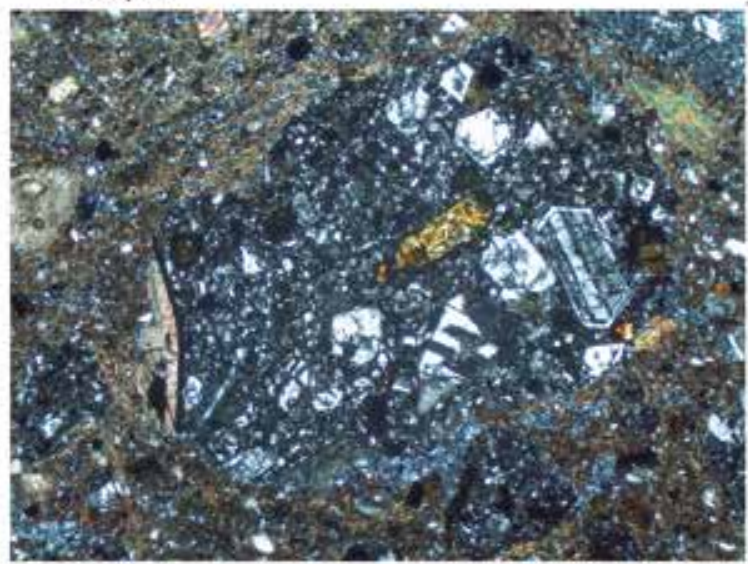

$800 \mu \mathrm{m}$
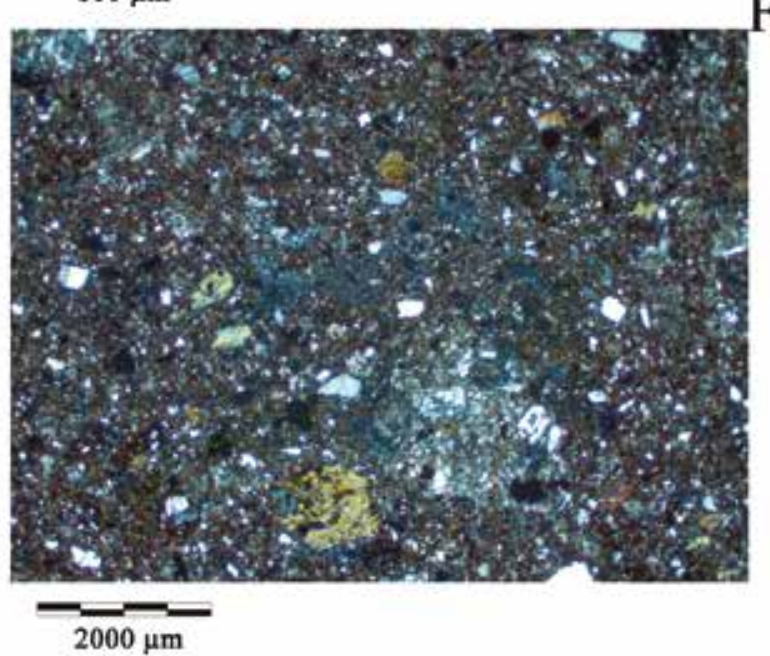

Fig. 4. Thin-section micrographs taken with cross-polarised light. A) Fine-textured Subfabric 1.1 containing basic igneous rocks; B) Plagioclase basalt fragment in Subfabric 1.1; C) Fine-textured Subfabric 1.2 containing intermediate volcanic rocks. D) Equant volcanic rock fragment with phenocrystals and microphenocryst of zoned plagioclase, hornblende and pyroxene in Subfabric 1.2. E) Medium-textured Subfabric 1.3 having intermediate volcanic rocks. F) Fine-textured Subfabric 1.4 having intermediate volcanic rock fragments./ Micrografías de sección fina tomadas con luz polarizada cruzada. a) Submuestra de textura fina 1.1 conteniendo rocas ígneas básicas; B) Fragmento de plagioclasa en submuestra 1.1.; C) Submuestra 1.1 de textura fina conteniendo rocas volcánicas intermedias; D)Fragmento de roca volcánica Equant con fenocristales y microfenocristal del plagioclasa zonificada, hornblenda y piroxeno en submuestra 1.2 E) Submuestra 1.3 de textura media con rocas volcánicas intermedias F) Submuestra 1.4 de textura fina con fragmentos de roca volcánica intermedia. 
with equant to prismatic seriated phenocrystals and microphenocrysts of plagioclase, brown amphibole and (less commonly) pyroxenes and amorphous nodules. In addition, the quantity of amphibole (brown hornblende) is higher in these sections - both in the coarse and fine fractions - while the amount of olivine is lower. The tcf observed in these samples differ from the ones observed in the previous subfabric, though they are also related to argillaceous rock fragments and clay pellets.

Subfabric 1.3: Coarse-grained Intermediate Igneous Subfabric (pyroxene andesite) (Fig. 4e). This subfabric differs due to its coarser texture and polymodal grain size distribution. In this subfabric, the coarse fraction is dominant, with a modal grain size of $0.5 \mathrm{~mm}$ in the long dimension (c:f10u: $v=73: 25: 2$ ). Plagioclase predominates within the coarse fraction, and there are basic and intermediate fine-grained igneous rock fragments (pyroxene andesite) with a porphyritic hypocrystalline structure formed by plagioclase along with seriated phenocrystals and micro-phenocrystals of plagioclase, orthopyroxene, clinopyroxene and, to a lesser extent, olivine. There are also a few aphyric rock fragments that have an isotropic fluidal groundmass containing only a few microlites of plagioclase. In addition, this subfabric has a lower amount of olivine and very few brown amphiboles. Finally, there are tcf related to argillaceous rock fragments.

Subfabric 1.4: Fine-grained Intermediate Igneous Subfabric (hornblende dacite) (Fig. 4f; sample C-22). The coarse fraction of this subfabric is characterized by the dominant presence of plagioclase and monocrystalline quartz, but mainly by the common presence of green hornblende. There are also a few rounded microcrystalline intermediate igneous rock fragments (andesite to dacite) with equant to prismatic phenocrystals and microphenocrysts of plagioclase, scarce quartz, and pure amorphous nodules. The groundmass is fine-grained and usually holocrystalline and porphyritic and consists of equant plagioclase crystals. There are also tcf related to argillaceous rock fragments.

\section{Fabric 2: Felsic Igneous Plutonic Fabric ( $n=9 ; 22 \%)$ (Figs. 5a \& 5b)}

There are few to very few open to single-spaced voids (3-10\%) in the microstructure of this fabric. The non-plastic inclusions are close to single-spaced and poorly oriented. The groundmass is dominant and relatively homogeneous throughout the sections. The variations between the samples are in terms of matrix colour, microstructure and the amount of non-plastic inclusions (10 to 35\%). The colour is usually yellowish-brown (PPL) to orange-brown (XPL). This is a stipple-speckled b-fabric with an optically active to moderately active micromass.

The inclusions usually have a polymodal grain size distribution with poorly sorted subangular to subrounded coarse inclusions (granules to fine sand) set in a fine grained groundmass with subrounded to rounded inclusions. The coarse fraction is dominant, with a modal grain size of $0.8 \mathrm{~mm}$ in the long dimension (c:f10 : $\mathrm{V}=$ 45:30:25 to 70:23:5). Monocrystalline quartz is dominant in the coarse fraction, although holocrystalline igneous felsic rock fragments (granodiorite to granite) with phaneritic texture, alkaline feldspar (sometimes with perthitic textures), plagioclase (usually altered to sericite) and biotite are also frequent or commonly observed in the sections. In addition, there is few polycrystalline quartz and very few to rare amphibole, clinopyroxene and pure amorphous nodules. There are some tcf related to argillaceous rock fragments and clay pellets.

\section{Fabric 3: Low-grade Metamorphic Fabric ( $n=5 ; 13 \%)$ (Fig. 5c)}

There are few open to single-spaced voids in these samples (5-8\%). The non-plastic inclusions are single-spaced and poorly oriented. The groundmass is dominant and homogeneous throughout the sections with a brown/greyish-brown (PPL) to orange-brown/ blackish-brown (XPL) colour. The micromass is optically active and related to a striated b-fabric. The inclusions have a bimodal grain-size distribution with poorly sorted subangular to rounded coarse inclusions and rock fragments (very fine granules to fine sand) set in a fine grained groundmass with subrounded to rounded inclusions. The coarse fraction is dominant with a modal grain size of $0.25 \mathrm{~mm}$ long dimension (c:f10 $\mathrm{f}: \mathrm{V}=60: 30: 10$ to $48: 36: 16)$. Monocrystalline quartz is dominant within the coarse fractions, although alkaline feldspar and plagioclase are also commonly observed in the sections. In addition, there are few polycrystalline quartz and quartzite rock fragments, as well as few to very few slate, sandstone, siltstone and chert fragments. Phyllite rock fragments, muscovite, biotite and pure amorphous nodules are very rare in the samples. Igneous rock fragments, tuff and calcimudstone are present in very low amounts in some samples. There are some clay pellets and argillaceous rock fragments.

\section{Fabric 4: Quartz-rich Fine-grained Fabric ( $n=2 ; 4.9 \%)$ (Fig. 5d)}

There are very few open to double-spaced voids in these samples (3\%). The non-plastic inclusions are single-spaced and non-oriented. The groundmass is homogeneous and dominant throughout the samples. The colour is brown (PPL) to reddish-brown (XPL). The micromass is moderately optically active and related to a stipple-speckled b-fabric. The inclusions range from a unimodal and bimodal grain size distribution with very few poorly sorted subangular to rounded coarse inclusions and rock fragments (very coarse to fine sand) set in a much finer-grained groundmass with subangular to rounded inclusions. The fine fraction is dominant, with a modal grain size of $0.12 \mathrm{~mm}$ in the long dimension (c:f10u: $v=23: 70: 7$ to 20:73:7). Monocrystalline quartz is predominant in the coarse fraction, but a 

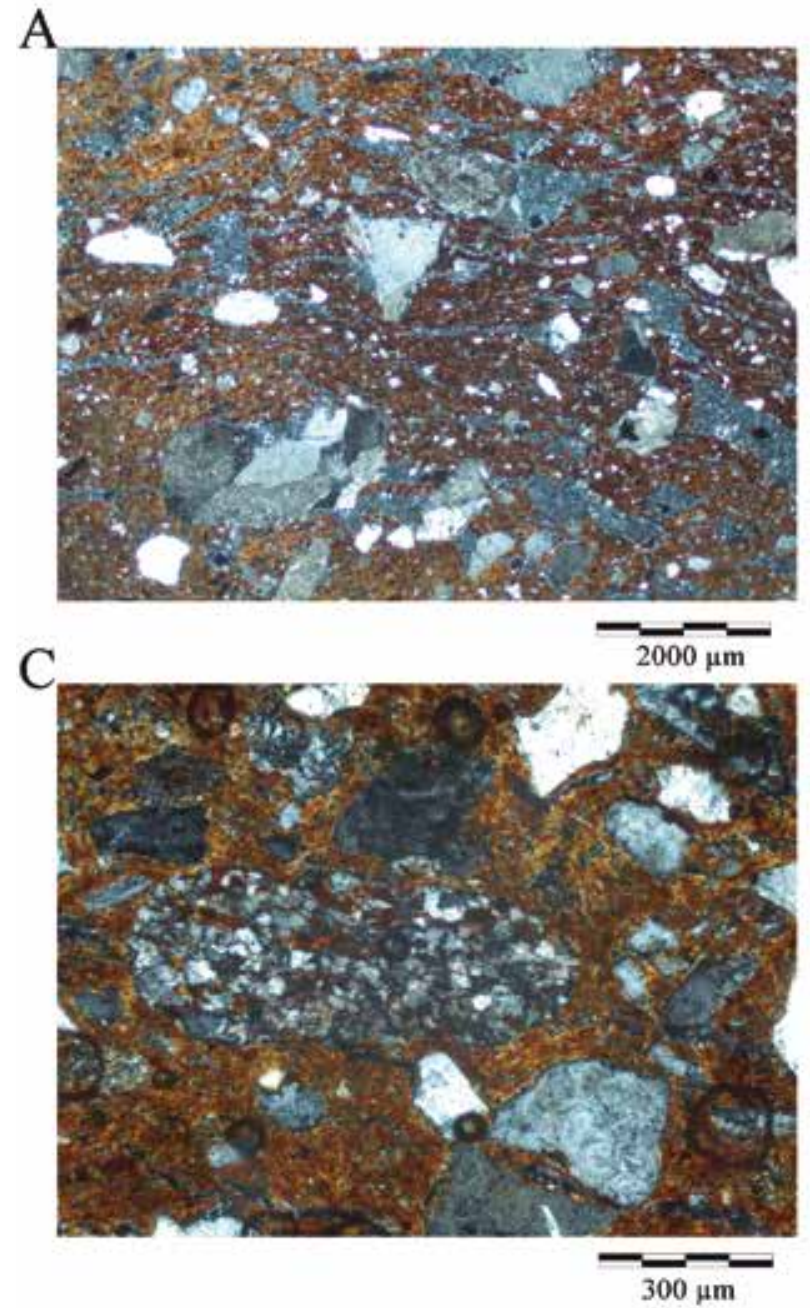
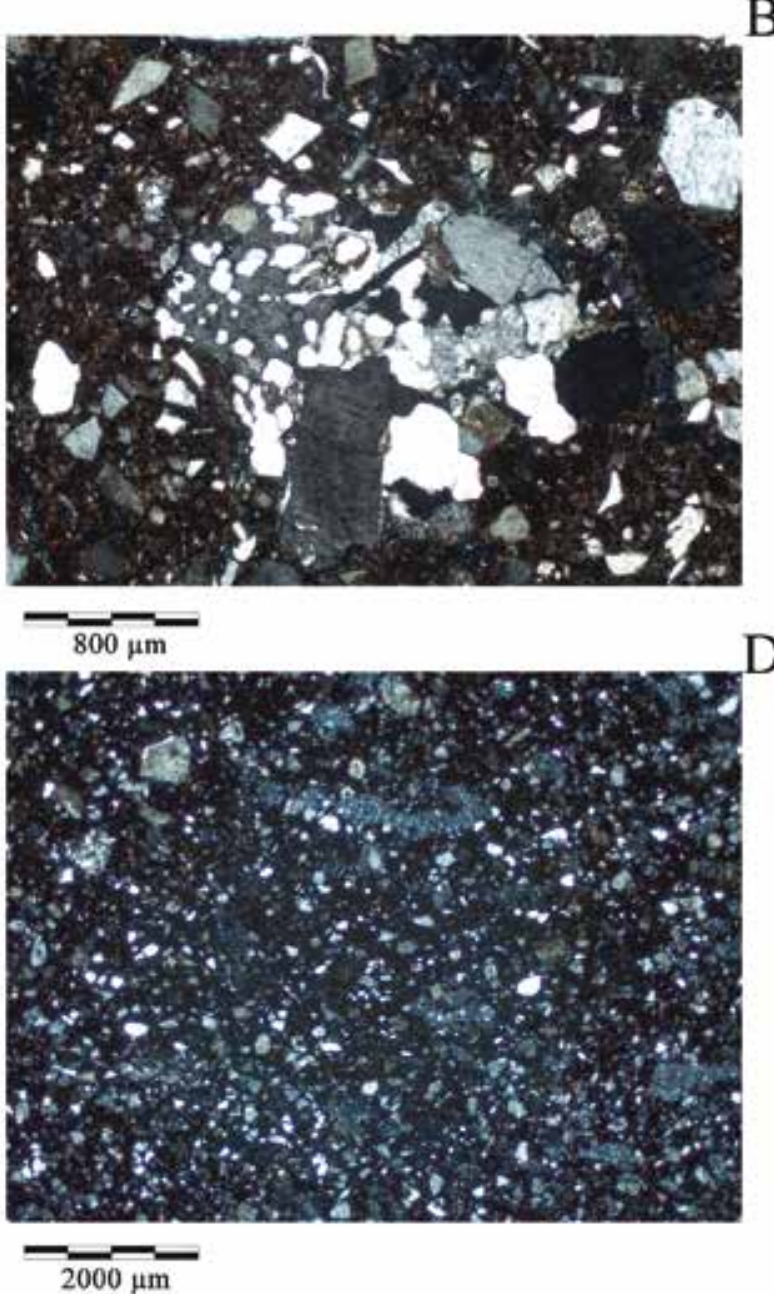

Fig. 5. Thin-section micrographs taken with cross-polarised light. A) Coarse-textured Fabric 2 made with clay derived from felsic plutonic igneous rocks (Image width $=8.3 \mathrm{~mm} ; \mathrm{XPL}$ ). B) Holocrystalline igneous intrusive rock fragment with phaneritic texture in Fabric 2; C) Low grade metamorphic rock fragment in Fabric 3: D) Fine-textured Fabric 4 rich in monocrystalline quartz. / Micrografías de sección fina tomadas con luz polarizada cruzada A) Muestra 2 de textura gruesa hecha con arcilla derivada de rocas igneas de félsico plutónico (Ancho de imagen $=8.3 \mathrm{mmm}, \mathrm{XPI}$ ), B) Fragmento de roca de holocristal igneo intrusivo con textura fanerítica en Muestra 2; C) Fragmento de roca metamorfica de grado bajo en submuestra 3; D) Muestra 4 de textura fina rica en cuarzo monocristalino.

significant amount of alkaline feldspar and plagioclase is also observed. In addition, there are very low quantities of sandstone, holocrystalline felsic igneous rock fragments, altered volcanic rock fragments, biotite and muscovite laths, siltstone, chert, micaceous rock fragments and pyroclastic textured rocks.

\section{Fabric 5: Calcareous Fossiliferous Fabric ( $n=10 ; 24.4 \%)$}

This is the most common fabric in Su Coddu/CaneIles, and its presence has already been identified in previous petrological analyses (Melis et al., 2006; Gradoli et al., 2013). These samples are related to the use of marly clays with sand and abundant microfossils, such us planktonic foraminifera (e.g. Globorotalia mayeri, Globigerinoides altiaperturus, Globorotalia continuosa, Praeorbulina glomerosa, Globigerinoides trilobus, Globorotalia peripheroacuta, Orbulina bilobata), benthic foraminifera (Lobatula lobatula, Bolivinidae), echinoderms, milliolids, bryozoa, bivalves and coralline red algae (Rodophycean). Many of these microfossils can be dated to the Miocene, specifically to the Langhian and Serravallian (Albero et al., 2016). Two subfabrics can be distinguished according to the texture of the samples.

Subfabric 5.1: Coarse-textured Calcareous Fossiliferous Subfabric (Fig. 6a). There are very few open-spaced voids in these samples (2-3\%). The non-plastic inclusions are single-spaced and poorly oriented. The groundmass is dominant and heterogeneous throughout the sections. The colour is light brown (PPL) to orange-brown (XPL). This is a crystallitic b-fabric with a highly calcareous and optically active micromass. The amount of inclusions ranges from 25 to $30 \%$. The inclusions have a bimodal grain size distribution with poorly sorted subangular to rounded coarse inclusions and rock fragments set in a finer-grained groundmass with 
subrounded to rounded inclusions (c:f10u: $\mathrm{V}=66: 24: 10$ to $57: 37: 6$ ). The coarse fraction (very fine granules and fine sand) is dominant, with a modal grain size of $1 \mathrm{~mm}$ long dimension. Monocrystalline quartz and alkaline feldspar are dominant within the coarse fraction. Plagioclase and biotite laths are also commonly observed in the sections. Moreover, few sandstones, siltstones and muscovite laths are also present in this subfabric. Slate, phyllite, igneous rock fragments and volcanic tuffs are observed in a very low amount in some samples. Many grains have a thin, moderately optically active coating along their perimeters containing iron oxide, providing a faint orange colour at the edges. This thin layer seems to be associated with pedogenic processes.

Subfabric 5.2: Fine-textured Calcareous Fossiliferous Subfabric (Figs. $6 b$ \& $6 c$ ). This subfabric has the same features as the previous subfabric. The main differences relate to the texture, since the proportion of inclusions in this subfabric ranges from 15 to $20 \%$. The inclusions consist of moderately sorted subangular to rounded coarse inclusions (coarse to fine sand) and rock fragments set in a much finer-grained calcareous groundmass with subrounded to rounded inclusions. The fine fraction is dominant, with a modal grain size of $0.12 \mathrm{~mm}$ in the long dimension ( $\mathrm{c}: \mathrm{f}_{10 \mu}: \mathrm{V}=17: 80: 3$ to $32: 53: 15)$. Most of the minerals and rocks are analogous to the ones identified in the previous subfabric. However, a wider variety of sandstones (i.e., quartzarenite, micaceous sandstone, calcareous sandstone, and arkose), more calcimudstone and few bioclasts, intraclasts, micro-spathic calcite, polycrystalline quartz and chert were observed in this subfabric. Clay pellets and argillaceous rock fragments were also identified.

\section{Fabric 6: Very Fine-grained Calcareous Fabric $(n=1$; 2.4\%) (Fig. 6d)}

This fabric has rare voids (1\%) and both pores and inclusions are open-spaced and non-oriented. The groundmass is highly calcareous, homogeneous and dominant throughout the section. The colour is light brown (PPL) to brown (XPL). Planktonic foraminifera (e.g., Globigerina) related to Langhian and Serravallian deposits and sponge spicules are very abundant in the sample. This is a crystallitic b-fabric with an optically active micromass. In this case, the amount of inclusions is low (10\%), and the inclusions have a unimodal grain size distribution with very few subrounded coarse inclusions (medium to fine sand) set in a very much finer-grained calcareous groundmass with well-rounded inclusions. The fine fraction is dominant in the sample, with a modal grain size below $0.12 \mathrm{~mm}$ in the long dimension (c:f $f_{10 \mu}: v=15: 77: 8$ ). The few inclusions observed within the coarse fraction consist of subrounded to rounded monocrystalline quartz, $\mathrm{k}$ feldspar and several chlorite laths. In addition, muscovite laths and plagioclase are also observed in the fine fraction. Finally, a number of pure amorphous nodules were observed in the section.
This highly calcareous fabric must be related to a figulina (i.e., a very plastic and light-coloured clay), a very fine raw material with silt and very fine sand that stands out because of its high number of foraminifera and spicules. Additionally, this unique sample lacks the metamorphic and igneous rock fragments observed in the other calcareous fabrics. Thus, the use of more distal sediments related to hemipelagic and turbiditic mudstones, which were formed at a greater depth than the other identified clays, can be assumed.

\section{Fabric 7: Calcareous Clay Tempered with Acid Igneous Rocks ( $n=5 ; 12.2 \%$ )}

The porous microstructure and groundmass of these samples is very similar to those of Fabric 5. However, the pores are open to single-spaced and the inclusions close to single-spaced and oriented parallel to the vessel margins in some samples. Slight differences are found in the groundmasses of two of the samples, which have a heterogeneous clay matrix with streaks. These streaks consist of black fringes with quartz and feldspar crystals, which are sorted by a grain size that differs from that observed in the primary clay matrix. This heterogeneity can be related to possible clay mixing, i.e., highly calcareous clay rich in foraminifera mixed with darker non-calcareous clay without foraminifera and less affected by alteration processes. Aside from this difference, there are only slight variations between the samples in terms of matrix colour and dominant grain size. The colour is light/dark brown to grey (PPL) and orange-brown to dark grey or brown (XPL). Some badly preserved planktonic foraminifera (e.g., Globigerina), benthonic foraminifera (Bolivinidae) and sponge spicules are present within the matrix. This is a crystallitic b-fabric with an optically active to moderately active micromass.

The amount of non-plastic inclusions is quite homogeneous (15-20\%). The inclusions have a bimodal grain size distribution with poorly to moderately sorted, angular to rounded, coarse inclusions and rock fragments (very fine granules to fine sand) set in a much finer-grained calcareous groundmass rich in subrounded to rounded inclusions. The texture is variable (c:f10 $: \mathrm{V}=$ $65: 25: 10$ to $24: 66: 10$ ), although the coarse fraction is usually dominant in almost all the samples, with a modal grain size of $0.5 \mathrm{~mm}$ in the long dimension. Plagioclase and alkaline feldspar (with some perthitic textures) are dominant in the coarse fraction. Monocrystalline quartz and bioclasts are also commonly observed in the sections. There are few to absent sandstones, wackestones, calcimudstones, siltstones, pure amorphous nodules, polycrystalline quartz crystals and muscovite and biotite laths. Finally, some volcanic and felsic igneous rock fragments could be rarely observed. Several tcf could be identified in some samples; they must be related to argillaceous rock fragments and clay pellets. Most of the inclusions and rock fragments observed in 
A
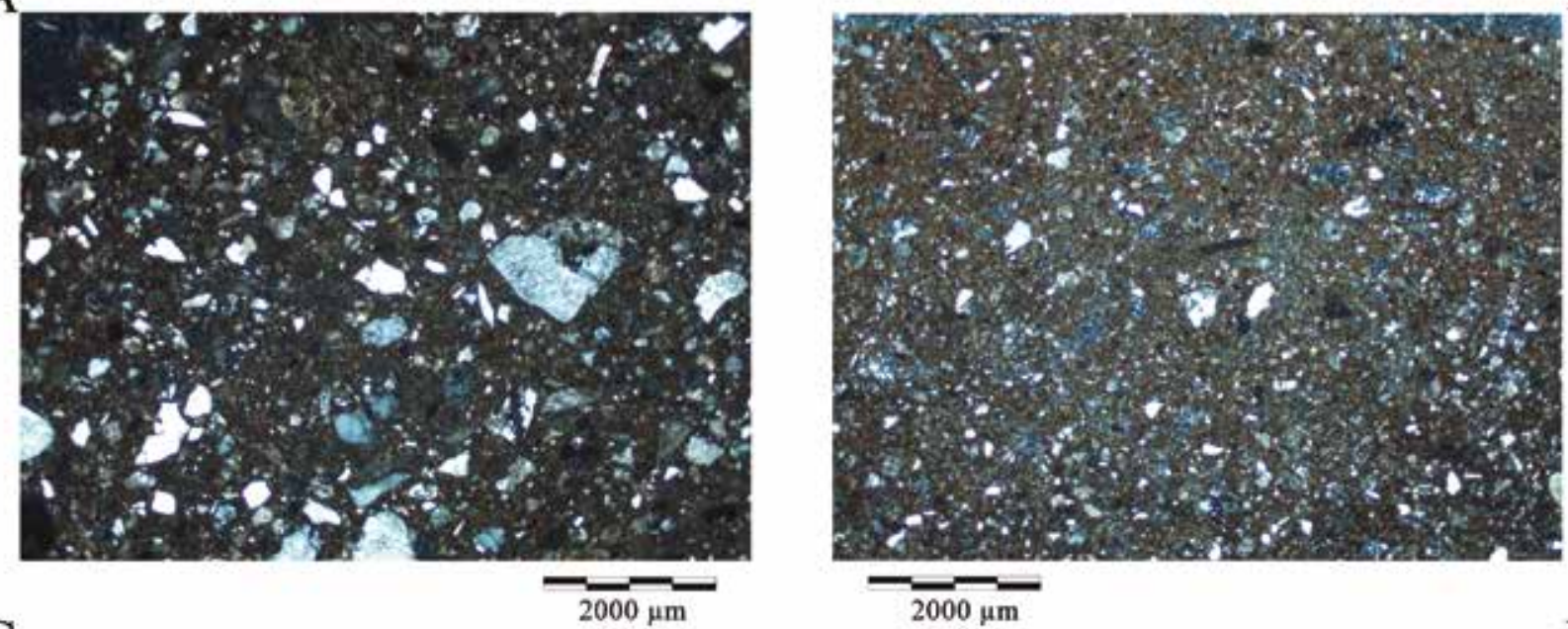

B
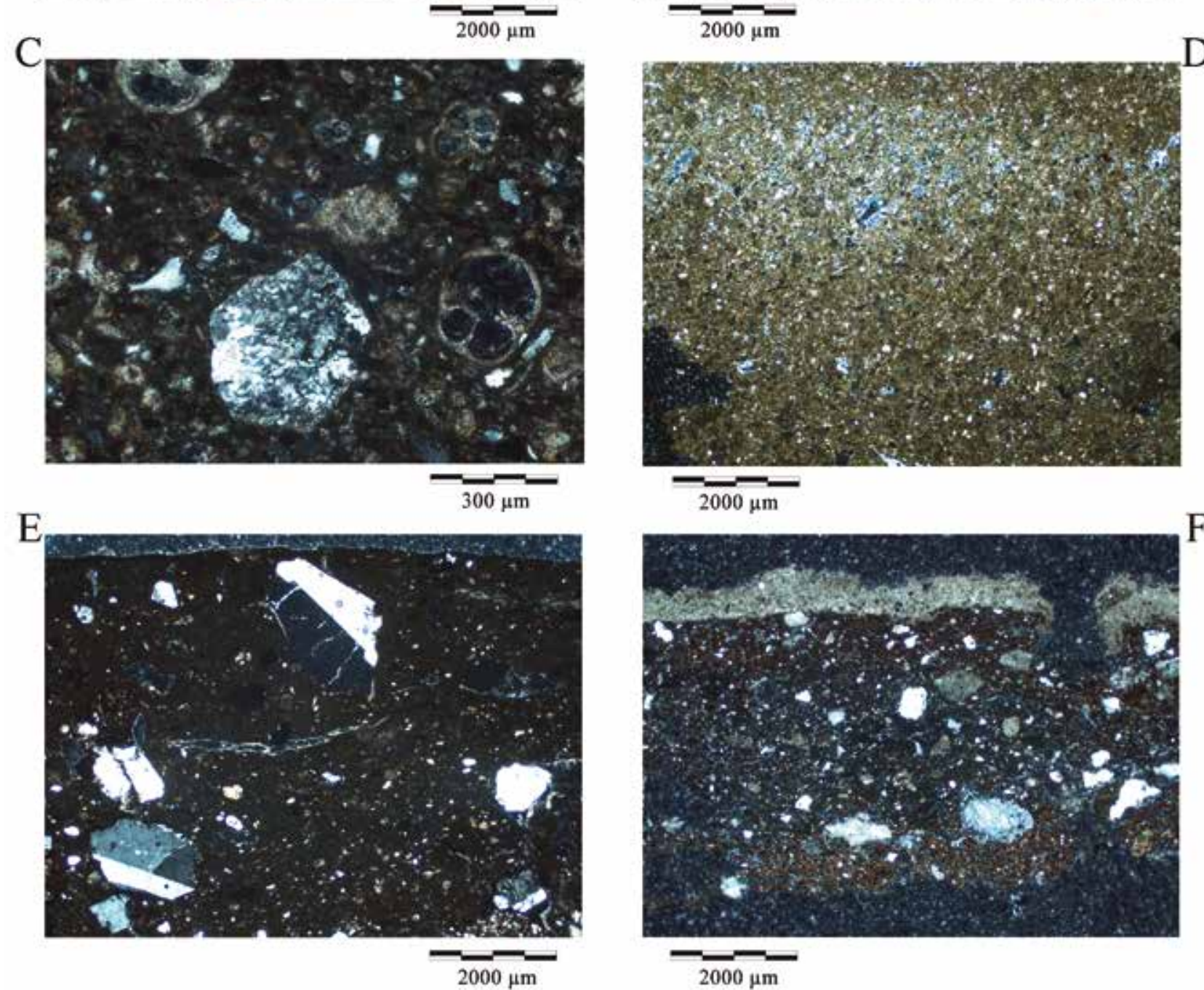

$2000 \mu \mathrm{m}$

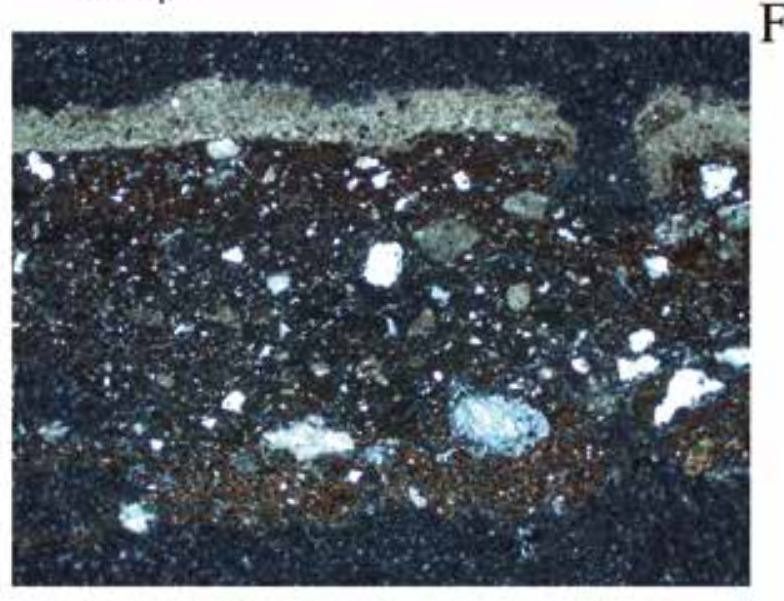

$2000 \mu \mathrm{m}$

Fig. 6. Thin-section micrographs taken with cross-polarised light. A) Coarse-textured calcareous Subfabric 5.1 that consists of a mix of metamorphic, sedimentary and igneous rock fragments; B) Thin-textured calcareous Subfabric 5.1 that consists of secondary fossiliferous marine clay containing a mix of metamorphic, sedimentary and igneous rock fragments; C) Foraminifera, siltstone and calcimudstone in fine-textured calcareous Subfabric 5.1; D) Very Fine-grained Calcareous Fabric 6; E) Fabric 7 that consists of secondary calcareous clay rich in microfossils and possibly tempered with felsic igneous rock fragments; F) Low Calcareous Fabric 8; Note the presence of completely alloctonous secondary calcite in the surface. / Micrografías de sección fina con luz cruzada polarizada A) Submuestra 5.1 calcareo de textura gruesa que consiste en una mezcla de fragmentos de roca metamórficas, sedimentaria e ignea B) Submuestra 5.1 calcareo de textura fina que consiste en arcilla de fosollifero marino secundario conteniendo una mezlca de fragmentos de roca metamorficos, sedimentarios e igneos; C) Foraminíferos, limolitas y rocas carbonatadas en la submuestra 5.1 de textura fina calcárea; D) Muestra 6 calcárea de grano muy fino E) Muestra 7 que consiste en arcilla calcárea secundaria rica en microfósiles y posiblemente templada con fragmentos de roca ignea felsica; F) Muestra 8 calcarea baja; Se nota la presencia de calcita secundaria complemetamente alóctona en la superficie. 
this fabric are surrounded by amorphous impregnated hypo-coatings, suggesting that the aggregates (e.g., siltstone and igneous rock fragments, clay pellets and alkaline feldspar) were formed by diagenesis or have a pedogenic origin.

Several aspects indicate that fine-grained calcareous clays were tempered with igneous rock fragments (up to 10\%) (Fig. 6e): 1) the coarse fraction includes angular crystals that have not been altered by the erosive processes that are expected in alluvial depositional environments. Additionally, this angularity has not been observed in any other calcareous fabric at the site. 2) The inclusions have a clear bimodal distribution, a feature that is related in most cases to the addition of a temper to the paste. 3) In contrast to the other calcareous fabrics, these samples do not have feldspar crystals altered to sericite, which indicates that the grains were not exposed to intense hydrothermal alteration processes.

\section{Fabric 8: Low Calcareous Fabric ( $n=2 ; 4.8 \%$ ) (Fig. 6f)}

The porous microstructure and groundmass of this fabric is very similar to those observed in Fabric 5. However, few planktonic foraminifera (e.g. Orbulina bilobata) and sponge spicules could be identified within the calcareous matrix. The amount of non-plastic inclusions is very homogeneous (15\%), and the inclusions have a bimodal grain size distribution with poorly sorted subangular to rounded coarse inclusions and rock fragments (very coarse to fine sand) set in a finer-grained calcareous groundmass with subrounded to rounded inclusions. The coarse fraction is dominant, with a modal grain size of $0.3 \mathrm{~mm}$ in the long dimension (c:f10 $: \mathrm{v}=45: 40: 15$ to 55:28:17). Monocrystalline quartz and alkaline feldspar are dominant within the coarse fraction and fine fraction, although plagioclase is also commonly present. There are also few siltstone, metasandstone and muscovite laths/flakes. Clay pellets are rarely observed in some samples. The samples of this fabric stand out because of their thinner walls and the lower abundance of microfossils and carbonate sedimentary rocks.

\section{DISCUSSION: LOCAL AND TRAVELLING POTS}

The petrological study of Su Coddu/Canelles pottery demonstrates the presence of a wide variety of fabrics related to different origins. Thus, the analysed ceramic assemblage can be divided into two main groups based on their association with local or regional materials.

\subsection{Local Pottery}

The most widely used raw material in Su Coddu/ Canelles is calcareous sedimentary clay rich in Miocene foraminifera and abundant inclusions consisting of fine sand and silt composed of sedimentary, granitic and metamorphic rock fragments. Thus, ancient craftspeople used marine clay deposits, alluvial sediments that primarily consisted of quartz/feldspar sandbars derived from the erosion of felsic igneous rocks and likely associated with the Sarrabus formation, and clasts of metamorphic rocks with a low degree of metamorphism. These alluvial materials were redeposited in the marine clays. The alteration of the feldspar to sericite indicates that these materials experienced significant hydrothermal processes, likely during redeposition. In addition, the well-documented presence of volcanic ash and tuff in the sections is related to the presence of pyroclastic facies associated with volcanic eruption events. In short, the optical analysis suggests the use of marly clays of marine origin for the production of a wide range of fabrics (Fabrics 5, 6, 7 and 8). The features of the marly clays used to produce the artefacts are in agreement with the composition of the Miocene deposits associated with the Marne di Gesturi, which appears in a significant area surrounding the site $(<1$ $\mathrm{km}$ ), or the Formazione di Fangario (BARCA et al., 2005). The latter deposit is well documented in the vicinity of the archaeological site, both in the west and under the Quaternary alluvial sediments (MAMELI \& MELIS, 2008).

It should be stated that there are certain differences between the identified calcareous fabrics. Although Subfabric 5.1, Subfabric 5.2 and Fabric 8 display certain similarities, they exhibit differences in grain size and the number of inclusions and microfossils. Different sources - either more proximal or distal - within the same marly clay deposit of marine origin are suggested for these fabrics. The same is true for Fabric 6 , which has a very low amount of coarse inclusions and is associated with the exploitation of a different resource. However, this material is also linked to coastal and lagoonal environments. This high variability regarding the procurement of local raw materials is not surprising, since (as previously mentioned) there are more than 10 archaeological sites in the vicinity of Su Coddu/Canelles (Melis, 2000). The short distance between these sites (usually $<2 \mathrm{~km}$ ) and the lack of natural or artificial defences suggest a shared management of the natural resources available and the absence of territorial competitiveness. Thus, potters could have used a wide variety of outcrops from this area. Nevertheless, it must also be considered that the individuals of this area could have transported local pottery in their trips between the different archaeological sites and Su Cod$\mathrm{du} /$ Canelles. Such social interaction is evidenced in the similarities in vessel shapes as well as in the decorative motifs identified in many of the archaeological sites in this area. For instance, the pottery assemblage at Su Coddu/Canelles shares its typological features with the ceramics recovered at nearby sites such as Terramaini or Craviole Paderi, located some $2.5 \mathrm{~km}$ and $6 \mathrm{~km}$ from Su Coddu/Canelles respectively. 


\subsection{Travelling Pottery}

Most of the analysed pottery cannot be related to sources located within less than $4 \mathrm{~km}$ of the site; thus, we must consider a non-local or regional origin for them. Therefore, non-calcareous fabrics (Fabrics 1, 2, 3 and 4) must be associated with clay deposits located at a greater distance (at least 7 to $15 \mathrm{~km}$ ) from Su Coddu/ Canelles. The presence of these fabrics at the site could be related to dynamics that do not fit with the statements previously suggested for the local calcareous fabrics. On the one hand, we must consider that these ceramics could have been produced at the site but using more distant and regional raw materials. There are ethnographic cases in which clays are procured from greater distances $(>4 \mathrm{~km}$ ) following the movement of people through a territory. This movement is performed on the basis of family ties or to conduct other activities, such as agriculture, trade or the search for raw materials for other crafts. In these cases, it is possible to collect small amounts of resources that are more limited in the territory during the trip (Albero, 2014). On the other hand, given the significant number of samples included in some of these fabrics (i.e., fabrics 1 and 2), we must also consider whether these vessels were manufactured at other archaeological sites instead of Su Coddu/ Canelles. Therefore, their presence in the site would be related to the movement of people and vessels through the territory on the basis of certain social interactions (e.g. family ties, exchange, gifts and counter-gifts, etc.).

Hence, to properly understand the mobility of these groups, it is essential to address the manner in which the territory was settled, the existing archaeological sites and their relationships to the available clay sources. These aspects could have determined the preference for exploiting certain raw materials, as well as the presence of pottery from certain locations in Su Coddu/Canelles. This research strategy requires linking the possible clay sources associated with the regional fabrics to the spatial distribution of Ozieri archaeological sites (Fig. 7) identified in southern Sardinia (Melis, 2000).

The diverse subfabrics comprising Fabric 1 can be related (within the regional geology) to the Late Oligocene Monte Zara and Monte Oladri formations. The presence of basaltic andesitic lavas, andesites and dacites with anhedral phenocrysts of amphibole and pyroxene is well documented in these formations. Nevertheless, the differences in the types of rocks, minerals and textures in the pottery samples suggest the use of different clay outcrops to make the vessels. The nearest deposit with such characteristics is located around Monastir, approximately $13 \mathrm{~km}$ northwest of Su Coddu/Canelles. Indeed, several archaeological sites occupied during the Ozieri II phase (e.g. Mitza Morta, Monte Zara, S'Ollastu, and Monte Olladiri) have been identified in the area of Monastir. These sites are related to such basic/ intermediate igneous formations and are likely to have provided either ceramics or raw materials to Selargius.
In addition, it is worth noting that almost all the samples of this fabric were recovered from the same archaeological context (structure 45) at the site. Furthermore, the ceramic assemblages from some archaeological sites in the vicinity of the Monastir area show a clear typological affinity with the pottery recovered at Su Coddu/ Canelles. This is the case of Is Arridelis, Perda Lada or Cuccuru Ambudu, among others, which are up to $11 \mathrm{~km}$ distant from Monastir.

A supra-regional origin must also be considered for the Fabric 1 vessels. Some of these vessels could have come from the Sulcis area (southwest of Sardinia) because Ozieri II archaeological sites (e.g. Montessu, Monte Crobu) are present in the area between Carbonia and Villaperuccio (57 and $44 \mathrm{~km}$ from Selargius, respectively) and are located very close to these Late Oligocene volcanic deposits. It is interesting to note that the vessels recovered from several archaeological sites (e.g. grotta A.C.A.I., Cronicario) in the Sulcis area present a significant typological and decorative similarity with the ceramic assemblage recorded at Su Coddu-Canelles. In this sense, some previous petrological studies conducted at the site of Is Calitas (Cara \& Manunza, 2005) and Su Coddu/Canelles (Melis et al. in press) suggest the use of volcanic materials from southwest Sardinia (Sulcis) to produce some vessels. Moreover, additional particular technological features may be associated with the allochthonous sample identified in the second archaeological site. This potential area of origin is very rich in certain valuable raw materials (for instance, copper and ochre), whose procurement and exchange might have favoured the mobility of the Early Copper Age groups and their ceramics. In this respect, we must take into account the possibility that the presence of this fabric in Su Coddu/Canelles is not related to geographical proximity criteria and is instead related to the existence of interactions and social ties between the inhabitants of the Sulcis and Cagliari areas.

Fabric 2 comprises a group of coarse-textured orange-coloured non-calcareous samples with abundant felsic rock fragments and poorly sorted sands composed of minerals (mainly alkaline feldspar, plagioclase, quartz and biotite) derived from these rocks. The evidence suggests that these samples must be related to primary clays originating from the erosion of granitic rocks. The features of these samples can be associated - within the regional geology - with the intrusive unit of San Gregorio, which is associated with several mountains and watercourses (e.g. the Brandanu River). The vessels of this fabric appear to share a common origin, though some differences between the samples, in terms of the amount of mafic minerals (biotite and hornblende), are observed. Such igneous deposits are located approximately $15 \mathrm{~km}$ to the west of the site. However, no Ozieri II archaeological sites have been identified in this area. The only site found there is Sa Forra (Burcei), which is situated approximately $20 \mathrm{~km}$ from Su Coddu/ Canelles. This site is associated with the Filigosa-Abe- 


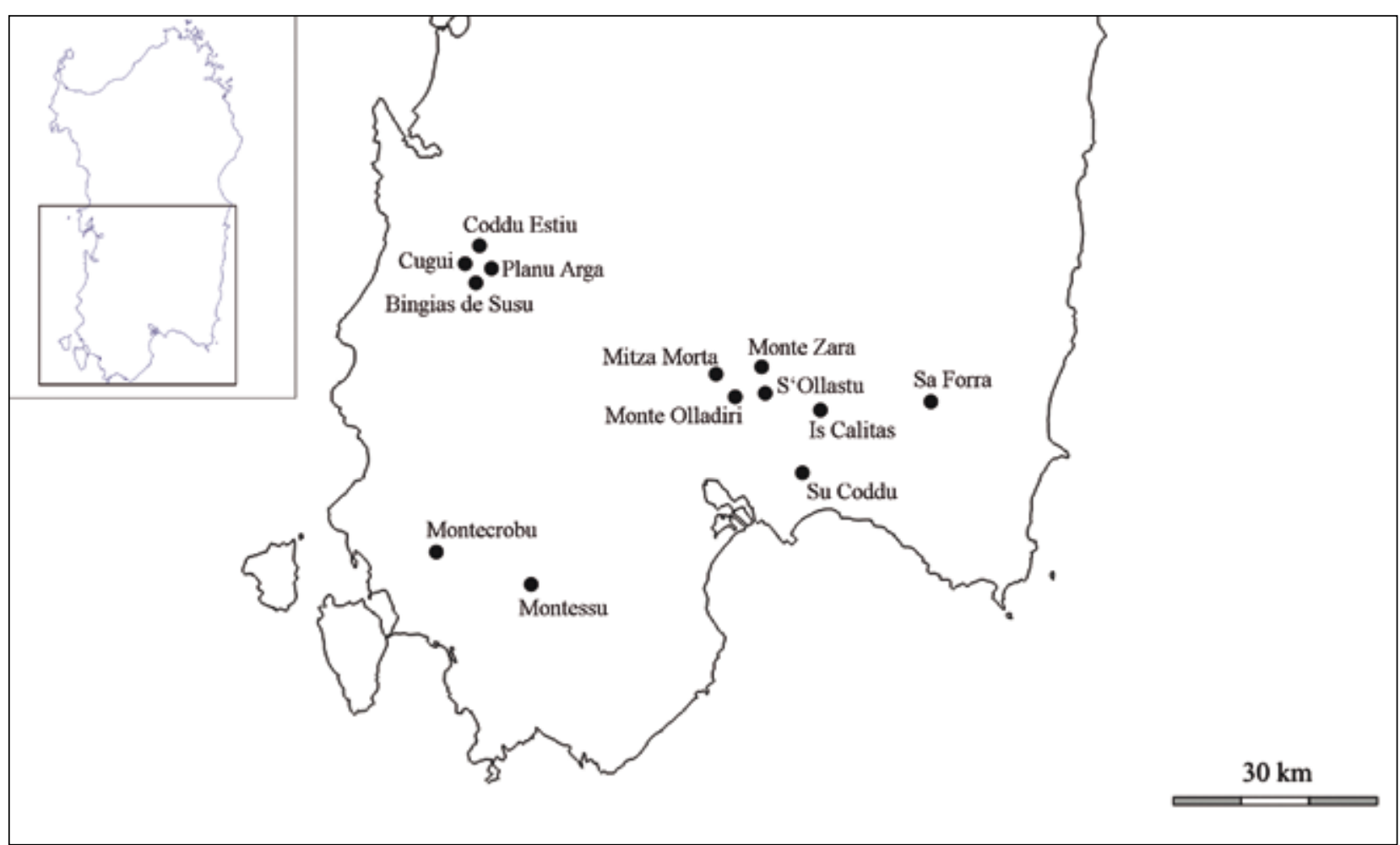

Fig. 7. Map of southern Sardinia showing the spatial distribution of Ozieri archaeological sites close to the raw material sources potentially used in the pottery samples studied from Su Coddu/Canelles./ Mapa del sur de Cerdeña mostrando la distribución espacial de yacimientos arqueológicos Ozieri próximos a las fuentes de material potencialmente utilizado en las muestras de cerámica estudiadas de Su Coddu/Cannelles.

alzu culture that began in c. 3000 BC and, therefore, postdates the Ozieri culture. Regardless, the marginal exploitation of mountain resources has been confirmed in Su Coddu/Canelles, based on, for instance, the presence of antler artefacts (Manca, 2013). Thus, there was at least an occasional link with this geographical area. Given these facts, a supra-regional origin must also be considered for the vessels of this fabric. In this regard, the closest Ozieri II archaeological sites associated with this type of geological deposits -i.e.,granitoids and granodiorites - are in the Arbus area (e.g. Coddu Estiu, Cugui, Planu Arga, and Bingias de Susu), which is approximately $57 \mathrm{~km}$ from Selargius.

Finally, Fabric 3 includes non-calcareous samples related to the use of clays with medium and fine sands and low-grade metamorphic rocks. These samples can be related to the Paleozoic metamorphic deposits observed in the region, such as the Pala Manna formation. In addition, they can also be associated with certain layers of the Punta Serpeddí and Tuvois formations, though both deposits contain microfossils that are not observed in the studied samples. These metamorphic deposits are located $7 \mathrm{~km}$ from the site, halfway between Selargius and the Monastir area. The archaeological site of Is Calitas is located in this area (approximately $9 \mathrm{~km}$ north of Su Coddu/Canelles), and the petrological analysis of its ceramic assemblage confirmed that potters at this site exploited local raw materials of metamorphic origin during the Ozieri II phase (Cara \& Manunza, 2005).
Different interpretations arise from the identified fabrics, the potential exploitation of certain clay sources and their relationships to other archaeological sites in the area. On one hand, there is the possibility that potters from Su Coddu/Canelles exploited a wide range of regional and perhaps supra-regional raw materials (in addition to several local clays) to produce their pottery. On the other hand, these samples could be related to pre-made pots transported to Su Coddu/Canelles from other regional or supra-regional sites.

If we assume that all the vessels were produced at the site, we can state that the potters would have used multiple local, regional and perhaps supra-regional clay sources without a clear preference for a particular type of material, thus generating a ceramic assemblage with high compositional variability. Consequently, this variability (at least in qualitative terms) must be linked, as noted above, to highly mobile potter communities during this period.

In contrast, as stated above, the compositional variability observed in the fabrics of the site - especially those related to regional or supra-regional raw materials - may be related to pottery exchange or travelling pots. In this scenario, we can assume that different individuals from diverse areas established contacts with the people inhabiting Su Coddu/Canelles, thereby providing the site with pottery from diverse regional or supra-regional locations. This would be the case of cera- 
mics made by human groups from the Cagliari area (in the vicinity of the site) but also from other regional sites located approximately $10 \mathrm{~km}$ to the north and northeast (Monastir and Soleminis areas) and even other supra-regional communities, such as the Arbus and Sulcis areas. In addition, we must also consider the possibility of contacts with the Burcei area, though no sites from this period have yet to be identified there.

The presence of vessels from these locations at Su Coddu/Canelles could have been strongly influenced by the nature of the site itself. It was indeed one of the largest sites of the Ozieri II phase found in the Cagliari area (Southern Sardinia) so far. In this sense, the site could have played a key role as a focal point, being fully involved in the development of social interactions at the regional level. This hypothesis would thus explain the significant presence of ceramics from diverse origins recovered at the site. In such situation, pottery could have played an identity role (either conscious or unconscious) related to the identification and visualization of the diverse groups settled in the region.

\section{CONCLUSIONS}

We have conducted the petrographic study of a ceramic assemblage from the site of Su Coddu/Canelles. The analysis has shown a wide diversity of pottery fabrics associated with raw materials of different origins. On one hand, a series of calcareous fossiliferous fabrics related to local resources from adjacent wetlands is observed. The use of Miocene marly clays with silt, coarse and fine sand, and microfossils is suggested for these fabrics. On the other hand, a series of igneous and metamorphic fabrics that must be related to regional or supra-regional origins was identified.

The petrological analysis and the identification of the potential clay deposits used in pottery production indicate that individuals of the Early Chalcolithic communities from southern Sardinia were highly mobile throughout the region. Moreover, the relationship between these regional and supra-regional sources with the spatial distribution in the area suggests that the presence of ceramics made from volcanic, granitic and metamorphic clays in Su Coddu/Canelles must be related to the travel of persons and pottery between Selargius and diverse distant areas. These vessels could have been brought to the site either by outsiders or by the inhabitants of Su Coddu/Canelles themselves in association with regional movement throughout the area and visits to other communities. One way or another, the presence of these ceramics in the archaeological site is evidence of the social interactions that existed between outsider groups and the communities that inhabited the lagoonal area located around Cagliari. These interactions strengthened the ties between the different communities and territories.

In addition to this explanation, the idea that these fabrics might also be related to a high mobility of the potters from Su Coddu/Canelles themselves must not be rejected. Craftspeople might have exploited a wide diversity of local as well as regional raw materials by means of movements through the territory. In this case, the significant variability observed in the ceramic assemblage of the site is explained by the high rate of mobility of the inhabitants, a relatively dispersed habitat in the region and the existence of a decentralized pottery production.

While these two proposed explanatory hypotheses imply a different degree of interaction between the groups settled in the region, we state that, in both cases, the procurement of regional sources of raw material indicates the existence of different potter communities or human groups involved in the displacement of the vessels. It must be noted that the broad regional mobility identified in our study for the Early Chalcolithic has also been documented in other dimensions of material culture. An increase in the supply of natural raw materials (e.g., hard materials of animal origin) in the two Ozieri phases, either at short, medium or long distances, has also been observed (Manca 2014). In this regard, the results provided by this research allow us to better understand the strategies of mobility developed by the Early Copper Age groups of southern Sardinia and to further deepen our understanding of the role that extensive and long-lasting sites, such as Su Coddu/Canelles, might have played in the Cagliari area and its adjacent territories.

\section{ACKNOWLEDGMENTS}

This paper was developed under the scientific objectives and funding of the research project Strategie insedative, aspetti funerari e socioeconomici, dinamiche dei rapporti uomo-ambiente naturale nella Sardegna preistorica sponsored by the Regione Autonoma della Sardegna (Italy). This contribution is also part of the activities of the research project HAR2015-67211-P: Archipiélagos: Paisajes, comunidades prehistóricas insulares y estrategias de conectividad en el mediterráneo Occidental. El caso de las Islas Baleares durante la Prehistoria, sponsored by the Ministerio de Economía y Competitividad (Spain).

\section{REFERENCES}

Albero, D., 2014. Materiality, Techniques and Society in Pottery Production: The Technological Study of Archaeological Ceramics through Paste Analysis. De Gruyter Open, Warsaw/Berlin.

Albero, D., Melis, M.G., Mateu, G., 2016. Landscape construction in southern Sardinia in the 4th Millennium BC: an approach using clay procurement. Periodico di Mineralogia 85(2), 151166.

Arnold, D., 1985. Ceramics theory and cultural process. Cambridge University Press, Cambridge.

Barca, S., Melis, E., Annino, E., Cincotti, F., 2005. Note Illustrative della Carta Geologica d'Italia alla scala 1:50.000, foglio 557, Cagliari. Servizio Geologico d'Italia. 
Broodbank, C., 1993. Ulysses without sails: trade, distance, knowledge and power in the early Cyclades. World Archaeology 24(3), 315-31.

Calvo, M., Albero, D., Javaloyas, D., García, J., 2013. Ceramic transactions in a multi-ethnic area (Upper East Ghana). Journal of Applied Clay Science 82, 3-9.

Cara, S., Manunza, M.R., 2005. Indagine archeometrica su materiali ceramici provenienti dagli scavi archeologici nel territorio di Soleminis. In: Manunza, M., Cuccuru Cresia Arta: indagini archeologiche a Soleminis, Dolianova, 273-288. Grafica del Parteolla.

Carmignani, L., Barca, S., Oggiano, G., Pertusati, P., Salvador, I., Conti, P., Eltrudis, A., Funeda, A., Pasci, S., 1996. Carta Geológica della Sardegna 1:200.000. Servizio Geologico Nazionale d'Italia

Cresswell, T., 2010. Towards a politics of mobility. Environment and Planning D: Society and Space 28(1), 17-31.

Cuomo di Caprio, N., Vaughan, S., 1993. An Experimental Study in Distinguishing Grog (Chamotte) from Argillaceous Inclusions in Ceramic Thin Sections. Archeomaterials 7(1), 21-40.

Gradoli, M.G., Manunza, M.R., Meloni, P., 2013. Artecraft at the prehistoric village of Canelles - Selargius (Cagliari, Sardegna) interpreted through its pottery technology. A petrological characterization study and a provenance analysis. 12th European Meeting on Ancient Ceramics (Padova).

Hommel, P., Day, P.M., Jordan, P., 2016. Context is Everything: Early Pottery, Hunter-gatherers and the Interpretation of Technological Choices in Eastern Siberia. In: Sibbesson, E., Jervis, B., Coxon, S., Insight from Innovation: New Light on Archaeological Ceramics, 1-18. Papers in Honour of Professor David Peacock. Southampton: Southampton Monographs.

Jordan, P., Gibbs, K., Hommel, P., Piezonka, H., Silva, F., Steele, J., 2016. Modelling the diffusion of pottery technologies across Afro-Eurasia: emerging insights and future research. Antiquity 90(351), 590-603.

Mameli, P., Melis, M.G., 2008. Intonaci in edifici in terra cruda negli abitati preistorici della Sardegna. Dati archeologici e archeometrici preliminari dal l'insediamento di Su Coddu/Canelles (Selargius, CA). $84^{\circ}$ Congresso della Società Geologica Italiana, 515-516. Rendiconti online della Società Geologica Italiana 3.

Manca, L., 2013. Fonctionnement des sociétés de la fin du Néolithique au début de l'âge du Cuivreen Sardaigne. Une approcheinédite à partir de l'étude des productions en matières dures animals. PhD dissertation, Université d'Aix-Marseille.

Manca, L., 2014. The individuation of a new Type of shell Tools during early Chalcolithic in Sardinia: The beveled Tools on oyster valves. An experimental approach to reconstruct the operational sequences. In: Margarit, M., le Dosseur, G., Averbouh, A. An overview of the exploitation of hard animal materials during the Neolithic and Chalcolithic, 155-182. Proceedings of the GDRE PREHISTOS work-session in Târgovişte.

Matthew, A.J., Woods, A.J., Oliver, C., 1991. Spots before the eyes: new comparison of charts for visual percentage estimation in archaeological material. In: Middleton, A., Freestone, I., Recent developments in ceramic petrology, 211-264. British Museum Occasional Paper 81

Melis, M.G., 2000. L'Età del Rame in Sardegna: Origine ed evoluzione degli aspetti autoctoni (Sassari). Soter, Sassari.

Melis, M.G., 2013. Problemi di cronologia insulare. La Sardegna trail IV e il III millennio BC. In: Cocch Genick, D., Cronologia assoluta e relativa del l'età del Rame in Italia, 197-211. QuiEdit.

Melis, M.G., In press. Modelli di sfruttamento e circolazione delle materie prime nel Mediterraneo occidentale durante il IV millennio BC. I dati della Sardegna. In: La Préhistoire et la Protohistoire des îles de Méditerranée Occidentale: Matières premières, circulation, expérimentation et traditions techniques.
Atti del workshop, Corte (France), 26-27 september 2016, Quaderni del LaPArS 3

Melis, M.G., Mameli, P., Piras, S., 2006. Aspetti tecnologici e morfologici della ceramica eneolitica. Nuovi dati dal l'insediamento di Su Coddu-Canelles (Selargius, Cagliari). In: Atti della XXXIX Riunione Scientifica del I'Istituto Italiano di Preistoria e Protostoria Materie prime e scambi nella Preistoria italiana Vol. II, 1232-1235. Istituto Italiano de Preistoria e Protostoria

Melis, M.G., Piras, S., 2010. Les productions céramiques en Sardaigne au IVe millénaire av. J.- C. Nouvelles données sur le village de Su Coddu-Canelles (Selargius, Cagliari). Préhistoires Méditerranéennes 1,101-118.

Melis, M.G., Piras, S., 2012. L'analisi morfo-tecnologica della ceramica come indicatore delle transformazioni tra l'Ozieri "classico" e "finale". In: Atti della XLIV riunione scientifica. La preistoria e la protostoria della Sardegna Vol. II, 563-569. Istituto Italiano di Preistoria e Protostoria.

Melis, M.G., Celant, A., Zedda, M., 2015. L'impatto di un ambiente umido nella paleoeconomia e nella paleonutrizione tra il Neolitico e l'Eneolitico. Nuovi contributi dalla Sardegna. In: L Riunione Scientifica del I'Istituto Italiano di Preistoria e Protostoria (Roma).

Melis, M.G., Mameli, P., Piras, S., In press. Caratterizzazione morfo-tecnologica e archeometrica delle ceramiche eneolitiche. Nuovi dati da Su Coddu/Canelles, lotto Badas (Selargius, Cagliari). Convegno di Studi La Sardegna nell'età del Rame (Olbia).

Neff, H., 2014. Pots as signals: Explaining the enigma of long-distance ceramic exchange. In: Martinón-Torres, M., Craft and science: International perspectives on archaeological ceramics. 1-11. UCL Qatar Series in Archaeology and Cultural Heritage, Bloomsbury Qatar Foundation.

Quinn, P., Day, P., Kilikoglou, V., Faber, E., Katsarou-Tzeveleki, S., Keeping an eye on your pots: the provenance of Neolithic ceramicsfrom the Cave of the Cyclops, Youra, Greece. Journal of Archaeological Science 37, 1042-1052.

Sheller, M., Urry, J., 2006. The new mobilities paradigm. Environment and Planning A 38, 207-226.

Skeggs, B. 2004. Class, Self, Culture. Routledge, London.

Whitbread, I., 1986. The characterization of argillaceous inclusions in ceramic thin sections. Archeometry 28(1), 79-88.

Whitbread, I., 1995. Greek Transport Amphorae: A Petrological and Archaeological Study. Athens: Fitch Laboratory Occasional Paper, 4, The British School at Athens. 
